\title{
Manuka honey enhanced sensitivity of HepG2, hepatocellular carcinoma cells, for Doxorubicin and induced apoptosis through inhibition of Wnt/ $\beta$-catenin and ERK1/2
}

\author{
Heba R. Al Refaey ${ }^{1}$, Al-Sayeda A. Newairy', Mayssaa M. Wahby¹, Chris Albanese², Mohamed Elkewedi \\ Muhammad Umer Choudhry and Ahmed S. Sultan ${ }^{1,4^{*}}$ (i)
}

\begin{abstract}
Background: Recently, there is increasing awareness focused on the identification of naturally occurring anticancer agents derived from natural products. Manuka honey $(\mathrm{MH})$ has been recognized for its biological properties as antimicrobial, antioxidant, and anticancer properties. However, its antiproliferative mechanism in hepatocellular carcinoma is not investigated. The current study focused mainly on investigating the molecular mechanism and synergistic effect of anticancer properties of $\mathrm{MH}$ on Doxorubicin (DOX)-mediated apoptotic cell death, using two different p53 statuses (HepG2 and Hep3B) and one non-tumorigenic immortalized liver cell line.

Results: $\mathrm{MH}$ treatment showed a proliferative inhibitory effect on tested cells in a dose-dependent manner with $\mathrm{IC}_{50}$ concentration of (6.92 $\pm 0.005 \%)$ and (18.62 $\pm 0.07 \%)$ for HepG2 and Hep3B cells, respectively, and induced dramatic morphological changes of Hep-G2 cells, which considered as characteristics feature of apoptosis induction after $48 \mathrm{~h}$ of treatment. Our results showed that MH or combined treatments induced higher cytotoxicity in p53-wild type, HepG2, than in p53-null, Hep3B, cells. Cytotoxicity was not observed in normal liver cells. Furthermore, the synergistic effect of $\mathrm{MH}$ and Dox on apoptosis was evidenced by increased annexin-V-positive cells and Sub-G1 cells in both tested cell lines with a significant increase in the percentage of Hep-G2 cells at late apoptosis as confirmed by the flow cytometric analysis. Consistently, the proteolytic activities of caspase-3 and the degradation of poly (ADP-ribose) polymerase were also higher in the combined treatment which in turn accompanied by significant inhibitory effects of pERK1/2, mTOR, S6K, oncogenic $\beta$-catenin, and cyclin D1 after $48 \mathrm{~h}$. In contrast, the MH or combined treatmentinduced apoptosis was accompanied by significantly upregulated expression of proapoptotic Bax protein and downregulated expression of anti-apoptotic $\mathrm{BCl}-2$ protein after $48 \mathrm{~h}$.
\end{abstract}

Conclusions: Our data showed a synergistic inhibitory effect of MH on DOX-mediated apoptotic cell death in HCC cells. To our knowledge, the present study provides the first report on the anticancer activity of $\mathrm{MH}$ and its combined treatment with DOX on HCC cell lines, introducing MH as a promising natural and nontoxic anticancer compound.

Keywords: Manuka honey, Doxorubicin, Hepatocellular carcinoma cells, Apoptosis Induction

*Correspondence: Dr_asultan@alexu.edu.eg; as4048@georgetown.edu ${ }^{1}$ Biochemistry Department, Faculty of Science, Alexandria University, Alexandria, Egypt

Full list of author information is available at the end of the article

\section{Background}

Hepatocellular carcinoma (HCC) is one of the most malignant tumors emanating from hepatocytes. It is the highest prevalent primary liver cancer, representing

(c) The Author(s) 2021. This article is licensed under a Creative Commons Attribution 4.0 International License, which permits use, sharing, adaptation, distribution and reproduction in any medium or format, as long as you give appropriate credit to the original author(s) and the source, provide a link to the Creative Commons licence, and indicate if changes were made. The images or other third party material in this article are included in the article's Creative Commons licence, unless indicated otherwise in a credit line to the material. If material is not included in the article's Creative Commons licence and your intended use is not permitted by statutory regulation or exceeds the permitted use, you will need to obtain permission directly from the copyright holder. To view a copy of this licence, visit http://creativeco mmons.org/licenses/by/4.0/. The Creative Commons Public Domain Dedication waiver (http://creativecommons.org/publicdomain/ zero/1.0/) applies to the data made available in this article, unless otherwise stated in a credit line to the data. 
the sixth most common cancer worldwide [1]. Moreover, HCC-related mortality ranks second globally, with a higher prevalence in males than females [1,2]. In developing countries, particularly those in East Asia and sub-Saharan Africa, the incidence of HCC and the consequent mortality are significantly higher than in their developed counterparts [1]. Egypt has been facing a growing incidence of $\mathrm{HCC}$, which represents the highest leading cause of local death among all other cancers [3]. This is mostly due to the high prevalence of endemic viral hepatitis, caused by hepatitis B (HBV) and hepatitis C viruses $(\mathrm{HCV})$, compared to other risk factors $[4,5]$. Both viruses are associated with the progression of a series of events, from chronic hepatitis to cirrhosis, then finally to HCC [1]. Since HCC has a very poor prognosis at the early stages, with rapid growth and a high rate of metastasis, most HCC patients are diagnosed at the advanced stages [6].

Currently, the conventional treatments for HCC, such as liver transplantation or resection [7], radiotherapy, and chemotherapy, have severe side effects. As drug resistance and adverse effects remain two critical hurdles [8], the necessity of beefing up the development of new anticancer agents has become apparent. For a substance to be utilized as a chemopreventive and chemotherapeutic agent in cancer treatment, it should exhibit high efficiency in hampering tumor growth, induce low side effects and alleviate the effect of carcinogenic agents [9]. Nowadays, significant awareness has been raised to identify naturally occurring anticancer agents derived from food and natural products. Among these natural products is honey, which has a potent anticancer effect, as it can suppress carcinogenesis by modulating or interfering with the molecular events of the initiation [10], proliferation [11], and progression stages [12].

Honey has a series of medicinal properties, such as anti-inflammatory [13], wound healing [14], anti-oxidative [15, 16], anti-diabetic [16, 17], antimicrobial [18], antibacterial [19, 20], antihyperlipidemic [21], antiproliferative, antimetastatic and antitumor properties [22]. These medicinal effects can be attributed to the various pharmacologically active constituents of honey, especially flavonoids and phenolic components [23, 24]. Therefore, kinds of honey possessing high phenolic and flavonoid content, such as Manuka Honey (MH) are deemed very medicinally attractive [24].

$\mathrm{MH}$ is monofloral honey obtained from the Manuka tree (Leptospermum scoparium), belonging to the family Myrtaceae, and collected by honey bees called (Apis Mellifera) in New Zealand and the Eastern region of Australia [25]. Isolation and characterization of the bioactive fraction of MH by using HPLC demonstrated that it comprises a complex mixture of carbohydrates, fatty acids, proteins, vitamins, and minerals containing various kinds of phytochemicals rich in polyphenols and flavonoids, that have been identified with potent ROS scavenging activity [25-29]. The major flavonoids are pinobanksin and pinocembrin, representing approximately $36 \%$ and $23 \%$ of the total flavonoid content, respectively followed by the presence of quercetin (11.81\%), luteolin (8.30\%), kaempferol (3.70\%), chrysin, and galangin. Leptosin derivatives and methyl syringate were characterized as the major compounds in $\mathrm{MH}$, representing approximately $35.5 \%$ and $43.87 \%$ of the total phenolic content, respectively [30, 31]. Moreover, $\mathrm{MH}$ contains other various phenolic compounds, such as apigenin, isorhammentin, 4-hydroxybenzoic acid, and caffeic acid. This dark honey has recently garnered a lot of attention and consideration for its biological properties, especially its antimicrobial effects, antioxidant efficacy, and potential role in wound healing [27, 32].

The current study sheds light on $\mathrm{MH}$ and its concurrent administration with Doxorubicin (DOX) as a potential anti-cancer agent. It has been priorly demonstrated that $\mathrm{MH}$ (Unique Manuka factor, UMF10+) inhibited cell proliferation in murine melanoma, colorectal carcinoma, and human breast cancer cells in a time- and dose-dependent manner [26]. However, the impact of $\mathrm{MH}$ on hepatocellular carcinoma (HCC) yet remained unknown.

Doxorubicin (DOX) is one of the most effective chemotherapeutic agents that is widely used to treat human malignancies [33]. DOX generates reactive oxygen species (ROS) that provoke the activation of caspases 8 and 3 respectively, thus triggering apoptosis via interaction with Fas-associated protein with death domain (FADD) [34]. Furthermore, DOX blocks DNA synthesis by inhibition of topoisomerase 2b (TOP2B) through intercalation into DNA [35]. Moreover, DOX causes early activation of p53 in tumor cells. Upon activation of the p53 pathway, the expression of the apoptotic regulatory protein, B-cell lymphoma 2 (Bcl-2) is decreased, whereas the downstream caspases, caspase- 9 , and caspase- 3 are activated, leading to apoptosis [36]. However, the clinical use of DOX is limited by its severe side effects and the associated developed drug resistance, thus, singleagent chemotherapy is no longer appropriate for treating human tumors. Recently, combination chemotherapy has emerged as a superior treatment strategy [37].

To the best of our knowledge, the present study represents the first report on the anticancer activity and apoptosis induction of $\mathrm{MH}$ and its combination with DOX on HCC cell lines. It is important to investigate the molecular mechanism of the role of $\mathrm{MH}$ and combined treatment on HCC cell growth inhibition. 


\section{Results}

MH inhibited HebG2 and Hep3B cell lines proliferation and viability

To determine the cytotoxic effect of $\mathrm{MH}$ or combined treatment with DOX on HCC cell lines, the MTT assay was performed on two different HCC cells, HepG2 and Hep3B, respectively. The cytotoxic effects of $\mathrm{MH}$ on HepG2 and Hep3B cells were examined by treating the cells with different concentrations of $\mathrm{MH}$ $(1.25-20 \%)$ for $48 \mathrm{~h}$, and the treated cells were normalized to the untreated cells as a control. The MTT assay demonstrated that the treatment of HepG2 or Hep3B cells with increasing concentrations of $\mathrm{MH}$ resulted in dramatic cell death and inhibition of cell viability in a dose-dependent manner compared to the control (Fig. 1a). Furthermore, $48 \mathrm{~h}$ of $\mathrm{MH}$ treatment, the effective significant inhibitory concentrations of $\mathrm{MH}$ started at $3.4 \%$ and $10 \%$ for HepG 2 and Hep3B cells, respectively. The concentrations at which $50 \%$ maximum inhibition of treated cell viability was achieved and $\mathrm{IC}_{50}$ were calculated, using a semi-logarithmic plotting of the percentage of cell viability versus the concentration used for $\mathrm{MH}$. The $\mathrm{IC}_{50}$ of $\mathrm{MH}$ for HepG2 and Hep3B cells was $6.92 \pm 0.005 \%$ and $18.62 \pm 0.07 \%$, respectively, as shown in (Fig. 1b, d). Combined treatment significantly showed a higher inhibitory effect on cell viability compared to single treatments with $\mathrm{MH}$ or DOX in the two tested HCC cell lines. However, HepG2 cells are significantly more sensitive to cell viability inhibition by $\mathrm{MH}$ than Hep3B cells. In addition, $\mathrm{MH}$ showed no significant cytotoxic effect on the primary human normal neonatal liver cells as shown in (Fig. 1c). In the present study, we focused on the mechanistic inhibitory effect of $\mathrm{MH}$ on HepG2 cells that showed a high sensitivity for $\mathrm{MH}$ or combined treatment with DOX after $48 \mathrm{~h}$.

To confirm the data of cell viability and elucidate the effectiveness of $\mathrm{MH}$, or combined treatment on HepG2 cell line, morphological changes of HepG2 cells treated with $\mathrm{MH}, \mathrm{DOX}$ as a positive control, or $1 / 2 \mathrm{IC}_{50} \mathrm{MH}$ plus $1 \mu \mathrm{M}$ DOX combined treatment were studied. The morphological changes of HepG2 were observed by inverted light microscopy as shown in (Fig. 2). After $48 \mathrm{~h}$ of treatment, the microscopic examination of HepG2 cells showed dramatic morphological alterations. HepG2 cells became rounded up and displayed a sharp reduction in both number and size. In addition, treated cells showed a complete loss of contact with the neighboring cells, apoptotic bodies, cell shrinkage, detaching from the culture plate, and broken cells compared to their untreated counterparts (Fig. 2). Combined treatment of $\mathrm{MH}$ with DOX showed the most dramatic morphological changes compared to treated cells with either $\mathrm{MH}$ or DOX. Taken together, $\mathrm{MH}$ or combined treatment induced morphological changes

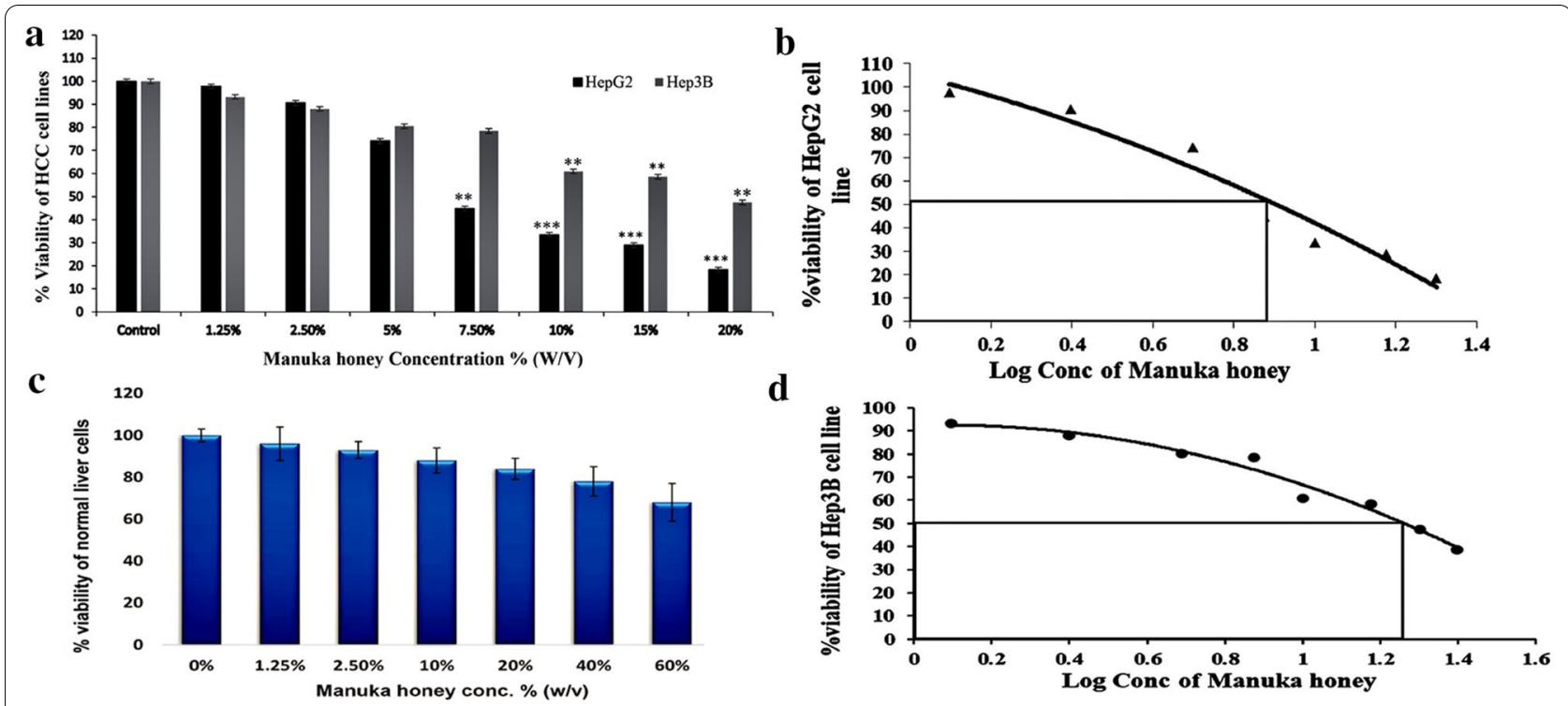

Fig. 1 a Inhibitory effect of Manuka honey on the viability of HepG2 and Hep3B cell lines: HepG2 and Hep3B cells were grown in a complete DMEM medium and treated with different concentrations of $\mathrm{MH}(1.25 \% \sim 20 \%)$ for $48 \mathrm{~h}$, and cells' viability was analyzed by MTT assay. Cell viability (\%) was compared to control (untreated). Each data point is an average of three independent experiments and expressed as $M \pm S D$. P-value ${ }^{*} \mathrm{P}<0.05:{ }^{* *} \mathrm{P}<0.01$ and ${ }^{* * *} \mathrm{P}<0.001$ compared to untreated control cells. $\mathbf{b}$, $\mathbf{d}$ Dose-response curve of Manuka honey of HepG2 and Hep3B cell lines. c Cell viability (\%) was compared to control (untreated) showed that MH has no significant cytotoxic effect on the primary normal human neonatal liver cells. The calculated $I_{50}$ of MH for HepG2 and Hep3B cells was $6.92 \pm 0.005 \%$ and $18.62 \pm 0.07 \%$, respectively. Each data point is an average of three independent experiments and expressed as \pm MSD. P-value ${ }^{*} \mathrm{P}<0.05$ : ${ }^{* *} \mathrm{P}<0.01$ and ${ }^{* *} \mathrm{P}<0.001$ compared to untreated control cells 

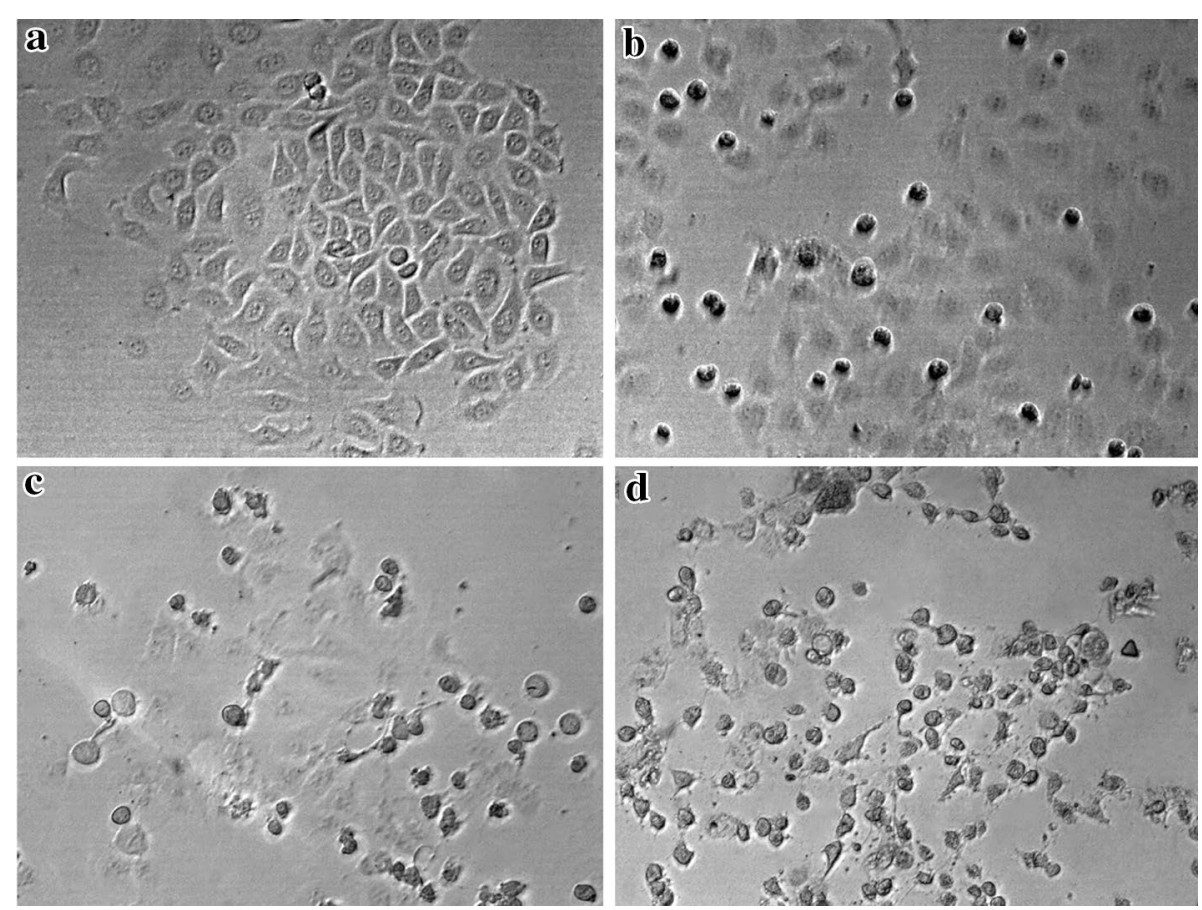

Fig. 2 Manuka honey treatment induced morphological changes of HepG2 cells. HepG2 cells were treated with or without as the following: (a) Control, (b) $1 \mu \mathrm{M} \mathrm{DOX}$, (c) $1 / 2 I_{50} \mathrm{MH}$, (d) $1 / 2 / \mathrm{C}_{50} \mathrm{MH}+1 \mu \mathrm{M}$ DOX. Cells were investigated under the inverted microscope at 400X magnification. The above data is representative of three independent experiments

with prompted characteristic morphological features of apoptosis in HepG2 cells.

\section{MH showed a synergistic effect with DOX on caspases} activity and apoptosis induction in HepG2 and Hep3B cells Indeed, apoptosis was quantified and visualized to determine whether the inhibition of cell viability by $\mathrm{MH}$ or combined treatment was due to apoptosis induction. [38]. To further investigate the inhibition in HCC cell viability after treatment with $1 / 2 \mathrm{IC}_{50}$ and $\mathrm{IC}_{50} \mathrm{MH}$, or ( $1 / 2$ $\mathrm{IC}_{50} \mathrm{MH}+1 \mu \mathrm{M}$ DOX) combined treatment, flow cytometric analysis was performed to examine and confirm the potential mechanism by which $\mathrm{MH}$ or combined treatment decreased cell viability. Loss of cell membrane asymmetry, one of the biomarkers of apoptosis, could be detected by Annexin V staining. It represents one of the earliest events in apoptosis (AV+/PI). Therefore, cells that are considered viable (control) are both $\mathrm{AV}$ and PI negative (AV-/PI-). On the contrary, the cells staining for both $\mathrm{AV}$ and PI $(\mathrm{AV}+/ \mathrm{PI}+)$, mark the late apoptosis stage. Thus, staining with FITC in conjunction with PI dye helps to identify cells in early and late apoptosis stages. HepG2 cells were collected after $48 \mathrm{~h}$ treatment with $\mathrm{MH}$, DOX, or combined treatment, then stained with Annexin V-FITC and PI, and finally subjected to flowcytometric analysis. The characteristic dot plots of (Fig. 3a-e) showed that the percentage of early apoptosis remarkably increased by $21 \%, 27 \%$, and $54 \%$ in HepG2 cells treated with MH, DOX, or combined treatment, respectively, compared to the untreated cells (Fig. 3a). Furthermore, there was a significant increase in the percentage of HepG2 cells at the late apoptosis stage by $48 \%, 55 \%$ and $81 \%$ after $48 \mathrm{~h}$ treatment with $\mathrm{MH}$, DOX, or combined treatment, respectively compared to untreated cells (Fig. 3b, d). In addition, combined treatment induced more dramatic apoptotic events in HepG2 cells compared to either $\mathrm{MH}$ or DOX alone, suggesting that $\mathrm{MH}$ and DOX act synergistically to inhibit cell proliferation and induced apoptosis in HepG2 cells.

To further elucidate the mechanism of cell growth inhibition, the cell cycle distribution was examined in Hep3B cells after treatment with MH, DOX, or combined treatment for $48 \mathrm{~h}$, and apoptotic cell death was quantified and determined by measuring the cellular DNA content by flow cytometry. After $48 \mathrm{~h}$ of treatments, our data showed that the percentage of sub-G1 cells was significantly increased by $\mathrm{MH}$, DOX, or combined treatment, and the apoptotic Hep3B cells (\%) in sub-G1 were $12.1 \pm 3.21 \%, 11.3 \pm 2.63 \%$, and $21.5 \pm 2.94 \%$, respectively, compared to $(1.21 \pm 1.06 \%)$ for control with the highest \% of sub-G1 was detected in combined treatment as shown in (Fig. 3f). Overall, these results illustrated that $\mathrm{MH}$ or 

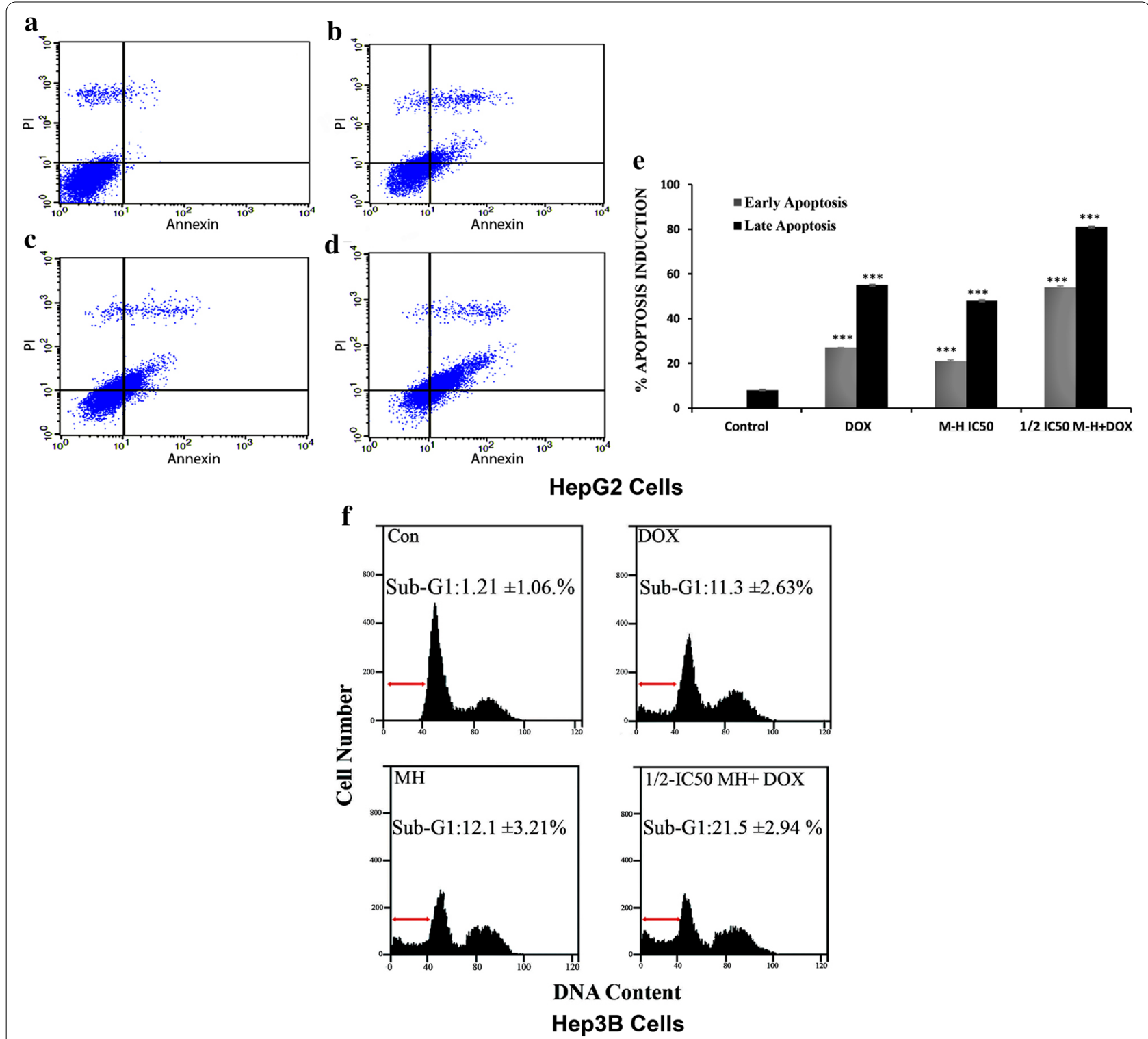

Fig. 3 Flow cytometric analysis of early and late apoptosis in treated HepG2 cells with MH, DOX, or combined treatment. HepG2 cells were treated with $\mathrm{MH}, \mathrm{DOX}$, or combined treatment for $48 \mathrm{~h}$, stained with FITC-conjugated AV and PI, and subjected to analysis by flow cytometer (a-d). The dot plot represents the untreated HepG2 cells as a control (a) treated cells with $1 \mu \mathrm{M} \mathrm{DOX}(\mathbf{b})$ treated cells with $1 / 2, \mathrm{C}_{50} \mathrm{MH}(\mathbf{c})$ and cells treated with $1 / 2$ IC $50 \mathrm{MH}+1 \mu \mathrm{M}$ DOX combined treatment $(\mathbf{d})$. The early apoptosis events ( $\mathrm{AV}+/ \mathrm{PI}-$ ) are shown in, the lower right panels. The late stage of apoptosis $(\mathrm{AV}+/ \mathrm{PI}+)$ is shown in, upper right panels. The bar chart represents the percentage of apoptosis induction in early and late apoptosis in treated HepG2 cells with $\mathrm{MH}, \mathrm{DOX}$, or combined treatment. e the results are shown as mean $\mathrm{M} \pm \mathrm{SD}$ of three independent experiments, and Statistical analysis was performed using one-way ANOVA with Tukey's post-hoc test ( ${ }^{*} P<0.05$, ${ }^{* *} P<0.01$, and ${ }^{* * *} \mathrm{P}<0.001$ ). f Cell cycle analysis of Manuka honey induced apoptosis in Hep3B cells. Induction of apoptosis by MH or combined treatment with MH and DOX in Hep3B cells. Hep3B cells were exposed to Control, $1 \mu \mathrm{M} \mathrm{DOX}, 1 / 2 \mathrm{IC} \mathrm{C}_{50} \mathrm{MH}$, and $1 / 2 \mathrm{IC}_{50} \mathrm{MH}+1 \mu \mathrm{M}$ DOX combined treatment for $48 \mathrm{~h}$. Cell cycle analysis was performed, quantified for treated-Hep3B cells, and (\%) sub-G1 was calculated, using flow cytometry as shown by histograms. The results were obtained from three independent experiments. The figures are representative of one of the experimental results

combined treatment has an antiproliferative effect on HepG2 cells via an apoptotic mechanism.

To examine the regulators that affected the treatment-induced apoptosis in HepG2 or Hep3B cells, caspase- 3 activity assays were performed after treatment with $\mathrm{MH}, \mathrm{DOX}$, or combined treatment for $48 \mathrm{~h}$. The combined treatment showed a higher increase in caspase-3 activity in both tested cell lines compared to control or individual treatments of $\mathrm{MH}$ or DOX, whereas caspase-3 activity was higher in HepG2 cells 
compared to Hep3B cells in all treated groups as shown in (Fig. 4a, b).

Caspase-3 activity was elevated by 3.5 -fold after $\mathrm{MH}$ treatment in a dose dependent manner and 4.3-fold with DOX in HepG2 cells. The $1 / 2 \mathrm{IC}_{50} \mathrm{MH}$ plus $1 \mu \mathrm{M}$ DOX combined treatment strongly stimulated the activation of caspase-3 in HepG2 cells by a 7.2-fold increase compared to the untreated cells as shown in (Fig. 4).

To further confirm if the reduction in the cell viability was due to apoptosis induction in tested HCC cell lines, an enzyme-linked immunosorbent apoptosis assay was performed, which determines the histone release from apoptotic cells. As shown in (Fig. 4), the treatment of HCC cell lines with MH, DOX, or $(1 / 2$ IC50 MH $+1 \mu \mathrm{M}$ DOX) combined treatment induced a significant histone release from fragmented DNA compared to the untreated control cells, and the \% of apoptosis induction was higher in case of HepG2 than Hep3B cells. Besides, the combined treatment demonstrated a higher degree of apoptosis induction than a single treatment of $\mathrm{MH}$ or DOX.

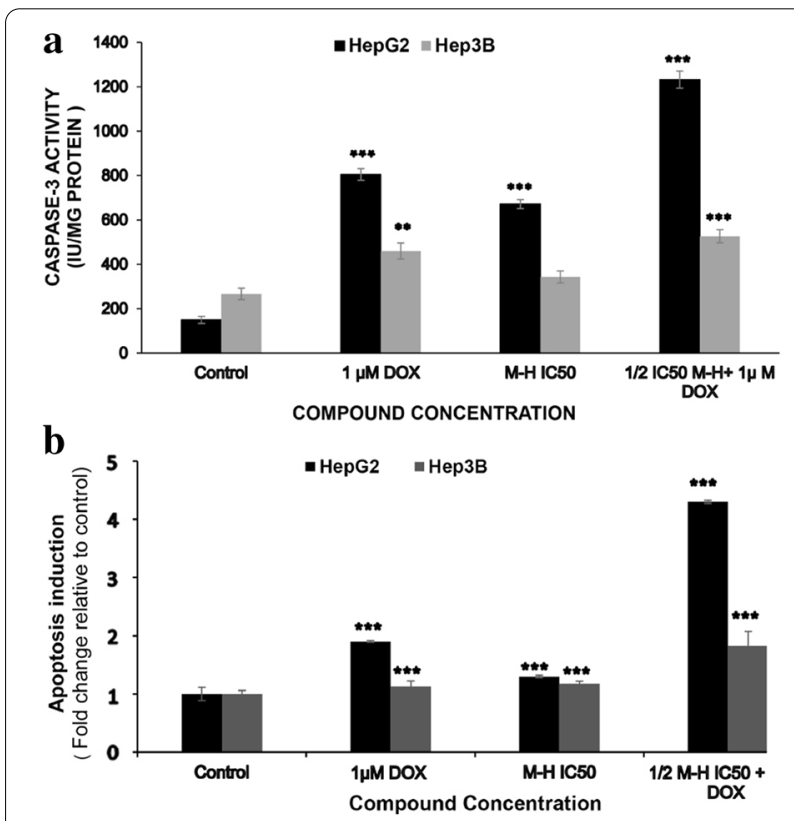

Fig. 4 Manuka honey induced Caspase-3 activation and apoptosis induction in HepG2 and Hep3B cell lines. a Caspases-3 activity in HepG2 and Hep3B cells. Cells were treated without/with MH, DOX, or combined treatment for $48 \mathrm{~h}$, and caspase-3 enzymatic activity was determined, using a specific colorimetric assay kit according to the manufacturer's protocol as explained in the Materials and Methods section. b Manuka honey induced Histone-release and apoptotic induction in HepG2 and Hep3B cells. Cells were treated without/ with $\mathrm{MH}, \mathrm{DOX}$, or combined treatment for $48 \mathrm{~h}$ and Histone-release activity was determined, using a specific ELISA assay kit according to the manufacturer's protocol. Each point is an average of three independent experiments and is expressed as $\mathrm{M} \pm \mathrm{SD}$. P-value was calculated versus control cells: ${ }^{* *} \mathrm{P}<0.01$ and ${ }^{* *} \mathrm{P}<0.001$
In HepG2 cells, the fold increase in the histone-release that results from the DNA fragmentation was elevated by 1.3-, 1.9-, and 4.3-folds for MH, DOX, or combined treatments, respectively, compared to the untreated cells, suggesting that the data of combined treatment of $\mathrm{MH}$ and DOX synergistically induced cell death is mainly due to apoptosis in the tested HCC cell lines that was consistent with our flow cytometry results (Fig. 3).

\section{MH induced apoptosis through modulation of apoptotic signaling-pathways}

Western blot analysis was performed for apoptotic markers to explore if the apoptotic induction was due to the activation of intrinsic or extrinsic apoptotic pathways. Many proteins involved in those pathways, were up-or down-regulated, according to their role in the apoptosis pathway. The Pro-apoptotic protein, Bcl-2 associated X protein (Bax), is one of the most important proteins that plays a critical role in the intrinsic apoptosis, and the poly (ADP-Ribose) polymerase (PARP) is a part of the caspase-dependent pathway of apoptosis also, it is cleaved by caspase- 3 and leads to apoptosis. Therefore, we investigated the expression level of Bax, Bcl-2, and PARP after $\mathrm{MH}$, DOX, or combined treatments for $48 \mathrm{~h}$. A reduction in $\mathrm{Bcl}-2$ expression and an increase in Bax expression were observed in HepG2 cells after treatment with $\mathrm{MH}$ or combined treatment compared to untreated cells. The cleavage expression of Bax and PARP was significantly increased after $48 \mathrm{~h}$ of treatment with $\mathrm{MH}, \mathrm{DOX}$, or combined treatment, and the highest effect was detected with combined treated cells compared to untreated cells (Fig. 5a). In addition, the most extensive increase in the levels of PARP cleavage was detected at $1 / 2$ IC50 $\mathrm{MH}+1 \mu \mathrm{M}$ DOX combined treatment, which revealed a $60 \%$ increase in PARP cleavage expression (Fig. 5b). Our data revealed that the combined treatment has a more profound effect on upregulation of the proapoptotic gene, Bax, followed by increasing caspase-3 activity, and in turn, PARP cleavage, suggesting a synergetic effect between $\mathrm{MH}$ and DOX that was consistent with apoptosis induction and growth inhibition in HepG2 cells.

\section{Suppression of $\mathrm{p}$-ERK $1 / 2, \mathrm{~m}$-Tor, and $\beta$-catenin signaling pathways associated with proliferation and cell survival by MH treatment in HepG2 cells}

An extracellular signal-regulated kinase (ERK), mammalian target of rapamycin (mTOR), and $\beta$-catenin signaling pathways play an essential and serious role in the pathogenesis of $\mathrm{HCC}$, including cell proliferation and cell survival; moreover, these pathways are up-regulated during the $\mathrm{HCC}$ advanced stage [39]. Therefore, the targeting of these pathways gives hope for novel targeted therapies to improve treatment opportunities for HCC. Therefore, we 


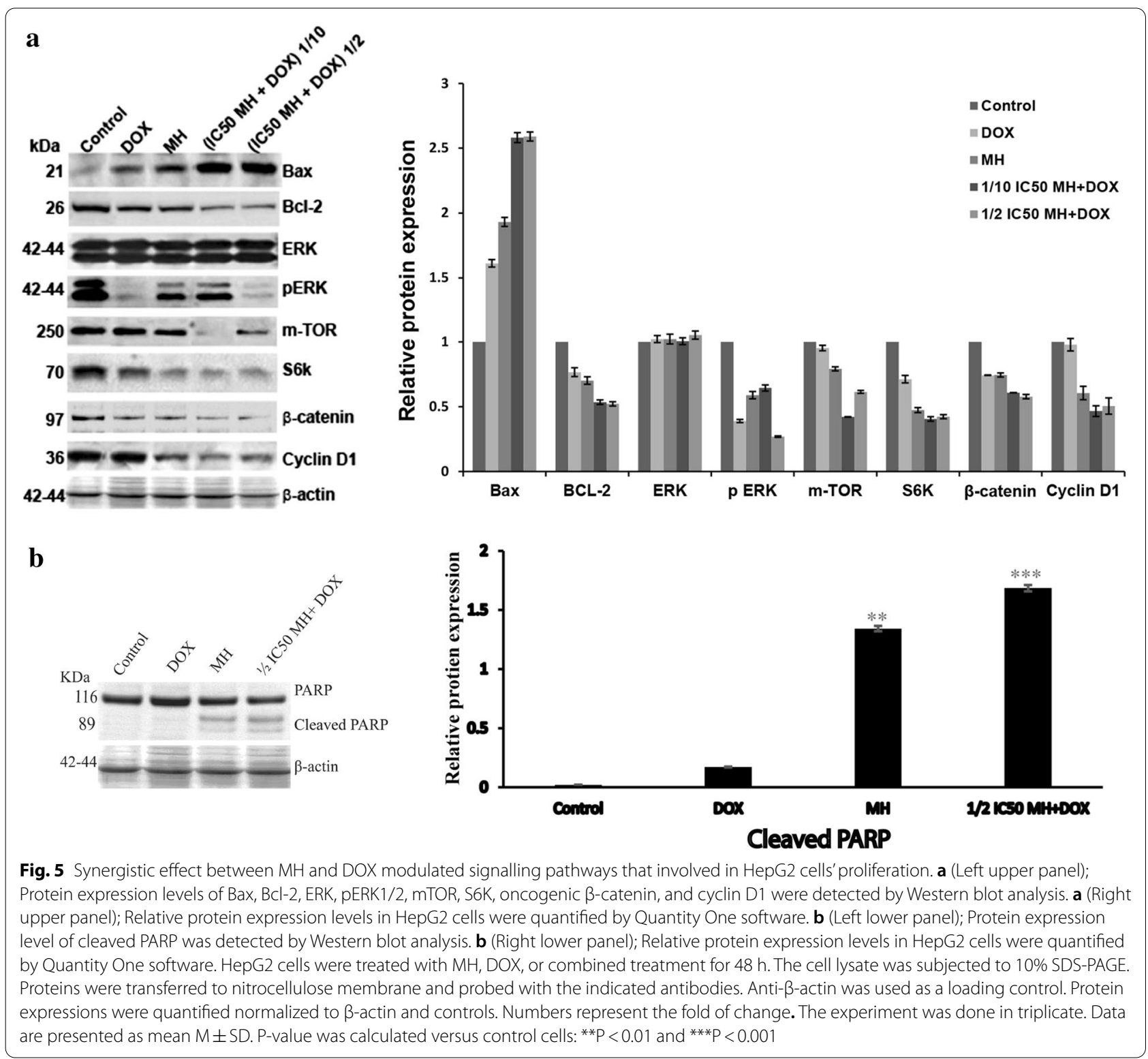

evaluated the protein expression of p-ERK 1/2, mTOR, S6 kinase (S6K), oncogenic $\beta$-catenin, and cyclin D1 by western blot analysis. HepG2 cells were treated with $\mathrm{MH}, \mathrm{DOX}$, or combined treatment for $48 \mathrm{~h}$. Compared to the control cells, $\mathrm{MH}$ or combined treatment significantly downregulated p-Erk1/2, mTOR, S6K, oncogenic $\beta$-catenin, and cyclin D1, while no significant effect on the total ERK1/2 was detected. In addition, the most profound reduction in the expression levels of the proteins p-Erk $1 / 2$ and oncogenic $\beta$-catenin was detected with the $1 / 2$ IC50 MH+1 $\mu$ M DOX combined treatment that showed a $73 \%$ and $42 \%$ reduction in p-ERK $1 / 2$ and oncogenic $\beta$-catenin protein expression, respectively, and by
$58 \%, 59 \%$ and $53 \%$ for mTOR, S6K, and cyclin D1 protein expression as shown in (Fig. 5a). Consistently, our results suggest that $\mathrm{MH}$ and DOX act synergistically to inhibit cell viability and induce apoptosis in HepG2 cells.

\section{Discussion}

The present study hypothesized that $\mathrm{MH}$ could be a potential candidate and a promising treatment option for HCC cell lines. Our results demonstrated that treatment of $\mathrm{MH}$ and particularly its synergetic effect with DOXinduced significant cytotoxicity and apoptosis induction in HCC cell lines, HepG2 and Hep3B, respectively in a concentration-dependent manner. It is worthy to note 
that Hep2G cells are significantly more sensitive to cell viability inhibition by $\mathrm{MH}$ or combined treatment than Hep3B cell line. Both HepG2 and Hep3B were derived from different hepatic progenitor origins and different stages of hepatocyte differentiation which in turn might explain the differences in $\mathrm{MH}$ or combined treatmentinduced cytotoxicity and apoptosis between Hep3B and HepG2 cells. In addition, MH had no significant cytotoxic effect on the human normal neonatal liver cells. In the present study, we focused on the HepG2 cells that showed a high sensitivity for $\mathrm{MH}$ or combined treatment with DOX.

Recently, there is an increased focus directed towards the identification and characterization of novel natural products, such as polyphenols and flavonoids-rich honey [40]. In addition, the new approaches to combined chemotherapies with polyphenols, or polyphenol-containing foods as honey becomes imperative to increase the effectiveness of the chemotherapy, also; this way can overcome the cancer cell resistance and minimize the adverse toxicity. Besides, the mixture of polyphenols existing in whole food is easily consumed and more effective when compared to the single or purified molecule in cancer prevention through synergistic and additive effects [41, 42].

Compared to other honey types, $\mathrm{MH}$ has been gaining traction in the research sector, since it is very rich in bioactive compounds such as phenolic and flavonoid compounds $[27,30,31]$. Afrin et al. has reported that $\mathrm{MH}$ is enriched with elevated levels of antioxidant compounds, at which the most abundant compounds are flavonols, for instance, quercetin represents $11.81 \%$, luteolin (8.30\%), and kaempferol (3.70\%) of the total phenolic content [31] and these three compounds have been identified in $\mathrm{MH}$ by Alvarez-Suarez et al. [30]. and by Marshall et al. [43] as well. In addition, phenolic compounds such as Gallic acid and syringic acid were the main components in $\mathrm{MH}$, which represents $36.57 \%$ and $32.55 \%$, respectively, of the total phenolic content, while the other phenolic acids such as.

4-hydroxybenzoic acid, apigenin, isorhammentin, and caffeic acid were presented in $\mathrm{MH}$ in low proportion [31]. $\mathrm{MH}$ has been identified with its potential anticancer activity [24]. The current study focused mainly on investigating the pro-apoptotic and anti-proliferative effects of MH in HepG2 and Hep3B cell lines. Moreover, our work was carried out, while taking into consideration a priorly conducted study, which demonstrated MH's safety by showing unaltered hematological and clinical chemistry profiles of MH treated mice [26]. Therefore, the anticancer effect of $\mathrm{MH}$ could potentially be specific to HepG2 and Hep3B cells since there is no cytotoxic effect on normal human neonatal liver cells, as opposed to that of the chemotherapy drug, doxorubicin, which was found to be toxic against the normal healthy cells.

Our MTT results proved the cytotoxic effects of $\mathrm{MH}$ and combined treatment with DOX on HepG2 and Hep3B cells after treatment with different concentrations of $\mathrm{MH}(1.25-20 \%)$ for $48 \mathrm{~h}$, suggesting that $\mathrm{MH}$ is effective in inhibiting HepG2 and Hep3B cells proliferation. Fernandez et al. reported on the $\mathrm{IC}_{50}$ values of $\mathrm{MH}$ on three different cancer cell lines. Firstly, the murine melanoma cells (B16.F1) after $24 \mathrm{~h}, 48 \mathrm{~h}$, and $72 \mathrm{~h}$ of exposure to $\mathrm{MH}$ (UMF10+) exhibited $\mathrm{IC}_{50}$ values of $2 \%, 1.3 \%$, and $0.8 \%$, respectively. Similarly, for colorectal carcinoma (CT26) cells, the $\mathrm{IC}_{50}$ values recorded at 24 and $72 \mathrm{~h}$, were $2 \%$ and $1 \%$ respectively. Whereas, the $\mathrm{IC}_{50}$ values for human breast cancer (MCF-7) cells, were more than $5 \%$ and $4 \%$ at 24 and $72 \mathrm{~h}$, respectively [26]. Furthermore, a previous study also demonstrated that the antiproliferative effect of $\mathrm{MH}$ was associated with the activation of the caspase-9-dependent apoptotic pathway [26]. Portokalakis et al. reported that $\mathrm{MH}$ showed cytotoxicity towards MCF-7 cells after $24 \mathrm{~h}$ treatment in a dose-dependent manner, and the concentration of $\mathrm{MH}$, which produced the $\mathrm{IC}_{50}$ values was $2.2 \%$ for UMF $18+$ honey and $4.7 \%$ for UMF $5+$ honey [44]. In the light of these findings, it has been noted that the $\mathrm{IC}_{50}$ values of $\mathrm{MH}$ vary among the different types of tested cell lines, according to their molecular, genetic characteristics, and progenitor origins. However, differences may also be attributed to the variations in the honey content, especially flavonoid and phenolic acids, which are responsible for the antitumor activities [26, 45]. According to the previous investigations, phenolic compounds such as quercetin, luteolin, kaempferol, gallic acid, and caffeic acid that are the major components in $\mathrm{MH}$, play an important role in the suppression of cancer cell proliferation [26, 41, 45, 46]. On the other hand, according to a previous study, the $\mathrm{IC}_{50}$ value of Adriamycin (Doxorubicin) for HepG2 cells was $1.12 \mu \mathrm{g} / \mathrm{ml}$, which is equivalent to $2 \mu \mathrm{M}$ [47]. It was previously reported that apigenin, a bioflavonoid present in honey) significantly reversed doxorubicin sensitivity in doxorubicin-resistant hepatocellular carcinoma cell line BEL-7402/ADM and induced caspase-dependent apoptosis [48].

The induction of apoptosis, along with targeting the pathways that regulate and coordinate cellular proliferation and differentiation, is regarded as an important targeted-therapy approach for cancer treatment. Cellular morphological changes are hallmarks of apoptosis and hence microscopic analysis is essential to observe these alterations [11]. Our results showed that the $\mathrm{MH}$ treatment of HepG2 cells resulted in apoptotic morphological features. The most pronounced morphological changes occurred at concentrations $\left(1 / 2 \mathrm{IC}_{50} \mathrm{MH}+1 / 2\right.$ 
$\left.\mathrm{IC}_{50} \mathrm{DOX}\right)$, combined treatment, compared to both the untreated cells and the positive control alone, hence confirming the synergistic effect of the combination treatment. Taken together with the data from the viability assays, this hinted towards the possibility of the potential involvement of an apoptosis-mediated, cellular proliferation inhibitory mechanism. Therefore, to investigate the inhibitory effects of $\mathrm{MH}$ or combined treatment, Annexin $\mathrm{V}$ assay was coupled with flow cytometry to quantify the $\mathrm{MH}$ and DOX treated HepG2 cells, undergoing early and late apoptosis. The Annexin V assay capitalizes on the apoptotic-characteristic early disruption of the plasma membrane and the consequent translocation of the membrane phospholipid, phosphatidylserine to the membrane outer surface. This change in locale facilitates the binding of the phospholipid-binding protein, Annexin V, to phosphatidylserine and thus allowing the detection of the cells undergoing early apoptosis. Whereas, the counterstain PI, is only capable of entering the cells once the integrity of their plasma membranes is greatly diminished, a feature exhibited by the cells undergoing late-stage apoptosis. In the present study, HepG2 or Hep3B cells were treated with $\mathrm{MH}, \mathrm{DOX}$, separately, or in combined treatment with $\mathrm{MH}$ and DOX for $48 \mathrm{~h}$. $\mathrm{MH}$ did not have a significant effect on normal human neonatal liver cells, whereas, in HepG2 and Hep3B cells, the combination treatment synergistically decreased cell viability as seen in (Fig. 1). Furthermore, combined treatment-induced cell death revealed features of apoptosis. The percentage of cells with annexin-V-positive staining and the population of sub-G1 cells, representing apoptosis induction, were also increased in HepG2 and Hep3B, respectively (Fig. 3). Our data showed that the percentage of HepG2 cells undergoing early apoptosis markedly increased to $21 \%, 27 \%$, and $54 \%$ following treatment with $\mathrm{MH}$, DOX, and/or combined treatment, respectively, compared to the untreated cells or single treatment of $\mathrm{MH}$ or DOX. Moreover, the percentage of HepG2 cells at the late apoptosis stage exhibited an increase to $48 \%$, $55 \%$, and $81 \%$ after $48 \mathrm{~h}$ treatment with $\mathrm{MH}$, DOX, or combined treatment, respectively, compared to untreated cells. Our data is in agreement with previous studies, where the mouse melanoma, B16.F1 cells, and human colon cancer, HCT-116 and LoVo, cells exhibited dosedependent apoptosis induction, upon treatment with MH [47].

The synergistic pro-apoptotic effect attained by using a combination of $\mathrm{MH}$ and DOX was evident by the enzyme-linked immunosorbent apoptosis assay on HepG2 cells revealed a significant induction of apoptosis. Hence, we decided to further study this effect on the activity of major apoptotic triggers. Bcl-2 and caspase-3 family members are crucial for the regulation of apoptosis. Moreover, the observed morphological features could be induced by caspase- 3 activation that is essential for the characteristic morphological alterations associated with apoptosis [49]. Therefore, we studied the effect of MH on HepG2 cells and focused on caspase-3, a key mediator of the mitochondrial apoptosis events [50]. Upon proteolytic activation by active initiator caspase (caspase-9), caspase-3 proceeds to cleave various substrates, such as poly (ADP-ribose) polymerase (PARP). The aforementioned cleavage of these substrates dictates the characteristic morphological and biochemical features evident in apoptosis [51]. To investigate if $\mathrm{MH}$ or the combined treatment would be able to activate caspase- 3 in the treated HepG2 and Hep3B cells, caspase-3 activity was assayed. Consistently with our earlier results, $\mathrm{MH}$, or combined treatment showed a significant increase in caspase- 3 activity in treated HepG2 and Hep3B cells compared to the untreated cells after $48 \mathrm{~h}$. While the highest increase in caspase-3 activity occurred at concentrations ( $1 / 2$ IC50 MH $+1 / 2$ IC50 DOX) of the combined treatment compared to the single treatment with MH or DOX. The data of HepG2 cells of caspase-3 and apoptosis induction was higher than those of Hep3B cells. Moreover, western blot analysis confirmed the cleavage of PARP and pointed towards the induction of apoptosis, after $\mathrm{MH}$, or combined treatment. All in all, our results suggested that $\mathrm{MH}$, or combined treatment induced apoptosis of HepG2 and Hep3B cells via an extrinsic or an intrinsic apoptosis pathway. Thus, we evaluated whether $\mathrm{MH}$ or combined treatment would be able to induce apoptosis in HepG2 cells through the signaling mediated extrinsic apoptosis pathway, or the cell stressmediated intrinsic apoptosis pathway. In this study, a reduction in $\mathrm{Bcl}-2$ expression and an increase in $\mathrm{Bax}$ expression were observed in HepG2 cells after treatment with $\mathrm{MH}$ or combined treatment, and the highest induction was detected in combined treatment. Western blot analysis for the pro-apoptotic protein, Bax, was found to be a transcriptional target of $\mathrm{p} 53$, a crucial tumor suppressor protein [52]. Moreover, p53, a transcriptional activator, was found to play a role in the induction of the transcription of many genes, including apoptosis-related ones. Therefore, the upregulation of Bax could be triggered via the p53 signaling cascade [52]. Besides, Bax plays an important role in controlling the mitochondrial disruption-mediated cell death, which is marked by the release of cytochrome $\mathrm{c}$ into the cytosol [12]. The Bax upregulation coincided with the increase in caspase- 3 activity that leads to the activation of PARP cleavage and consequently cell death, suggesting that $\mathrm{MH}$ or combined treatment induced apoptosis in HepG2 cells via the activation of the intrinsic (mitochondrial) apoptosis pathway. Consistent with our results, a previous report 
also showed that $\mathrm{MH}$ triggered apoptosis in murine melanoma cells (B16.F1) via the activation of the intrinsic apoptosis pathway [26]. Furthermore, it was reported that the antiproliferative effect of $\mathrm{MH}$ was brought about through the activation of the caspase-9 dependent apoptotic pathway, leading in turn to the activation of caspase-3, reduced Bcl-2 expression, DNA fragmentation, and finally cell death [26]. Moreover, another study demonstrated that Chrysin, a common flavonoid of $\mathrm{MH}$, induced apoptosis via the activation of the p53/Bcl-2/ caspase-9 pathway in HCC (HepG2) cells [53]. Furthermore, Im et al. reported that luteolin (the major phenolic compound of $\mathrm{MH}$ ) activated caspase- $8,-9$, and -3 , and cleaved PARP in human hepatocellular carcinoma SKHep-1 cells [54]. Besides, it was reported that quercetin (common flavonoid of $\mathrm{MH}$ ) remarkably inhibited HCC cell (HepG2 and SMCC-7721) proliferation and induced apoptosis by upregulating the expression of Bad and Bax and downregulating the expression of $\mathrm{Bcl}-2$ in vitro [55].

RAF/MAPK/ERK signaling pathway is activated in $\mathrm{HCC}$ and was found to correlate with the advanced stage of the disease [39]. Therefore, we evaluated the potential effect of $\mathrm{MH}$ on the RAS/ERK pathway by studying the protein expression of total ERK1/2 and their phosphorylation by western blot. The phosphorylation of ERK1/2 is essential for their activation, and hence studying their phosphorylation and relating it to the total protein abundance, sheds light on the potential effect of $\mathrm{MH}$ or combined treatment on ERK1/2 activity. The treatment of HepG2 cells with MH, or combined treatment for $48 \mathrm{~h}$, elicited a significant decrease in the p-ERK $1 / 2$, despite the total ERK1/2 abundance exhibiting no marked changes. In addition, the most profound reduction in $\mathrm{p}$-ERK1/2 and was recorded with the combined treatment of $\left(1 / 2 \mathrm{IC}_{50} \mathrm{MH}+1 \mu \mathrm{M}\right.$ DOX), which showed a $73 \%$ reduction in the p-ERK $1 / 2$, reaffirming the synergistic effect of the combination employed, suggesting the anticancer and antiproliferative effect of $\mathrm{MH}$ might be mediated through the RAS/ERK signaling pathway. Complementing our data, a priorly conducted study has revealed that Gelam honey alone and /or combined with ginger, induced early apoptosis, partly through the RAS/ ERK pathway, in colorectal cancer cells [56]. Furthermore, Ding et al. demonstrated that quercetin reduced cell viability, induced apoptosis, cleaved caspase-3, cleaved PARP, upregulated Bax protein expression, and downregulated p-ERK1/2 protein levels in HepG2 cells [57]. Shao et al. demonstrated that phytochemicals, such as apigenin (one of the flavonoids present in $\mathrm{MH}$ ), downregulates the activation of ERK and Akt in human colon cancer cells [58]. Moreover, ERK1/2 has been previously implicated with $\beta$-catenin, mTOR, and cyclin D1 in cellular proliferation $[39,59]$. Hence, studying the abundance of these proteins following the treatment of HepG2 cells with $\mathrm{MH}$ should help to better understand the underlying molecular mechanisms associated with the anti-proliferative and pro-apoptotic effect of the honey.

mTOR and its downstream effector, S6K, are important regulators of protein translation. Moreover, the mTOR signaling pathway was found to upregulated in several carcinomas, including HCC, where overexpression of S6K was recorded in nearly half of the studied HCCs [60]. Furthermore, the Wnt/ $\beta$-catenin pathway (Canonical Wnt signaling) has been found to enhance the m-TORmediated modulation of S6K [61]. The crosstalk between the RAS/ERK and mTOR signaling pathways to positively and negatively regulate one another is well documented, while the simultaneous inhibition of both pathways induced an anti-proliferative effect on different cancer cells [62]. The protein expression of both mTOR and S6K in HepG2 cells following treatment with $\mathrm{MH}$, DOX, or combinations of $\mathrm{MH}$ and Dox showed inhibition in cell proliferation, where both proteins exhibited a significant downregulation, with the most marked inhibition being evident in the cells treated with combinations of $\mathrm{MH}$ and DOX. The present results may be attributed to quercetin (one of the major phenolic compounds of $\mathrm{MH}$ ). $\mathrm{Wu}$ et al. reported that quercetin inhibited the proliferation of HCC cells via the downregulation of hexokinase-2 (HK2) protein level and suppression of the AKT/mTOR pathway [63]. In addition, Ji et al. have demonstrated that quercetin induced autophagy via inhibiting the AKT/ mTOR pathway in HCC [64]. Another study reported that luteolin reduced cell viability and induced apoptosis in prostate cancer cells, besides, it downregulated AKT, ERK, mTOR, and P70S6K [65]. Luteolin downregulated the protein expression levels of phosphorylated Akt, mTOR, p70S6K, and MAPK, also induced caspase and PARP cleavages in glioblastoma cells and promoting cell cycle arrest [66].

Moreover, we further studied the effect of $\mathrm{MH}$ on the oncogenic $\beta$-catenin expression, a transcription factor, which plays a critical role in HCC progression. $\beta$-catenin is a multifaceted protein, as it plays an integral role in the maintenance of the E-cadherin-catenin cell adhesion complex in the cellular junctions, through mediating the binding of cadherins to the actin cytoskeleton [67]. In addition, $\beta$-catenin is also a key protein in the canonical Wnt signaling pathway [68]. The activation of this pathway induces the cytoplasmic accumulation of $\beta$-catenin and its consequent translocation into the nucleus, thus triggering the transcription of downstream target genes [69]. The Abnormal upregulation of the $\mathrm{Wnt} / \beta$-catenin signaling pathway is the hallmark of many tumors, including liver cancers, where the upregulation of $\beta$-catenin plays an important role in the development and 
progression of HCC [68]. Therefore, various approaches have been conceived and executed throughout the past years to target the $\mathrm{Wnt} / \beta$-catenin pathway, as a means to develop novel therapies for HCC treatment [70]. The treatment of HepG2 cells with $\mathrm{MH}$ or combined treatment resulted in a significant reduction in the abundance of $\beta$-catenin, with the most profound decrease being recorded under the combined treatment, comprising both $\mathrm{MH}$ and DOX.

In the light of our western blot results, we assumed that there is a connection between the decreased p-ERK1/2 and the decrease in $\beta$-catenin expression. This inhibition pattern of $\beta$-catenin expression correlates with the decreased $\mathrm{p}$-ERK1/2, implying that $\mathrm{MH}$ may be down-regulating $\beta$-catenin through the Ras/ERK signaling pathway. Benn et al. revealed that around $50-70 \%$ of HCC patients exhibited increased p-ERK due to the activated RAS/ERK pathway. The activation of this pathway is associated with the inhibitory phosphorylation of Glycogen synthase kinase 3 beta (GSK-3 $\beta$ ), which acts as a negative regulator of the canonical Wnt signaling, resulting in the inactivation of GSK-3 $\beta$ and the accumulation of $\beta$-catenin [71]. The $\left(1 / 2 \mathrm{IC}_{50} \mathrm{MH}\right.$ plus $1 \mu \mathrm{M}$ DOX) combined treatment markedly reduced the protein expression levels of $\beta$-catenin in HepG2 cells after $48 \mathrm{~h}$, effectively validating the synergistic effect of the combined treatment $\mathrm{MH}$ and DOX. Consistent with our results, It was uncovered that $\mathrm{MH}$ possesses components, such as polyphenols and quercetin flavonoids, which were found to contribute to its antiproliferative properties, through reducing $\beta$-catenin/Tcf transcriptional activity and down-regulating the canonical Wnt signaling pathway in colon cancer cells [63]. Moreover, the $\mathrm{MH}$ bioflavonoid Galangin was found to diminish the $\beta$-catenin response transcription (CRT), which is abnormally elevated in colorectal and liver cancers [72]. This bioflavonoid acts by enhancing the degradation of the intracellular $\beta$-catenin, as well as restraining the $\beta$-catenin/T-cell factor-dependent gene expressions, such as cyclin D1 and c-myc. Thus, it consequently exerts an anti-proliferative effect on the CRT-positive cancer cells [72]. In conclusion, the phytochemicals present in $\mathrm{MH}$ suppressed $\beta$-catenin in HepG2 cells, thus contributing to the MH's anti-cancer effect [73].

Previous studies demonstrated that the overexpression of cyclin D1 could be attributed to $\beta$-catenin activation and the RAS/ERK signaling pathway [74, 75]. Cyclin D, a crucial regulator of the cell cycle progression, is overexpressed in different cancers, especially in HCC [76]. Moreover, it is a downstream target of $\beta$-catenin and RAS/ERK signaling pathway in HCC, where the increased p-ERK1/2, results in elevated expression of cyclin D1 and the inhibitory phosphorylation of the tumor suppressor protein, $\mathrm{pRb}$ [77]. Besides, the overexpression of cyclin D1 was found to be involved in HCC tumor cell differentiation, therefore targeting cyclin D1, is regarded as an alternative approach in cancer therapy [78]. In the present study, the cyclin D1 expression in $\mathrm{MH}$ treated HepG2 cells, revealed a significant downregulation with the most significant decrease being exhibited by the cells treated with combined treatment. Our data demonstrated that cyclin D1 might be one of the downstream targets of $\beta$-catenin and ERK1/2 in HepG2. Consistent with our results, $\mathrm{MH}$ contains high amounts of quercetin, which can profoundly inhibit the growth and proliferation of HepG2 cells by reducing the expression of cyclin D1 [79].

\section{Conclusion}

All in all, to our knowledge, the present study provides the first report on the anticancer activity of $\mathrm{MH}$ on HCC cells. Moreover, combined treatment of $\mathrm{MH}$ and DOX showed a potent therapeutic effect more than the individual treatment through inhibition of several oncogenic signal transduction proteins oncogenic $\beta$-catenin, pERK1/2, mTOR, S6K, and cyclin D1. Furthermore, we uncovered a potential correlation between p-ERK1/2, $\beta$-catenin, S6K, and cyclin D1, which might be responsible for the anti-cancer effect of $\mathrm{MH}$ or combined treatment. We also demonstrated the possibility of apoptosis induction via Bax upregulation and down-regulation of Bcl-2, followed by the activation of caspase- 3 that caused an elevation in DNA fragmentation, leading to increased histone release, increased PARP cleavage, and finally cell death. Hence, a possible molecular mechanism, underlying the observed antiproliferative and proapoptotic activity of $\mathrm{MH}$ or the combined treatment of $\mathrm{MH}$ and DOX in HCC progression was illustrated as shown in (Fig. 6). Taken together, the present study serves to shed light on the anticancer mechanism of $\mathrm{MH}$ and its synergistic inhibitory effect on DOX-mediated apoptotic cell death in HCC cell lines, while introducing the naturally occurring, $\mathrm{MH}$, as a promising antitumor and non-toxic candidate with possible potential effective adjuvant therapeutic for HCC treatment.

\section{Material and methods \\ Cell line}

HCC Hep3B and HepG2 cells were obtained from the American Type Culture Collection (Manassas, VA, USA). Cells were maintained in Dulbecco's modified Eagle's medium (DMEM) supplemented with 10\% (v/v) fetal bovine serum (FBS), (100 IU/ml) penicillin/ streptomycin, and $(50 \mathrm{IU} / \mathrm{ml})$ Fungizone (all reagents were produced by Lonza Bio-Whittaker, Walkersville, USA). The cultures were maintained at $37{ }^{\circ} \mathrm{C}$ in $5 \% \mathrm{CO}_{2}$ 


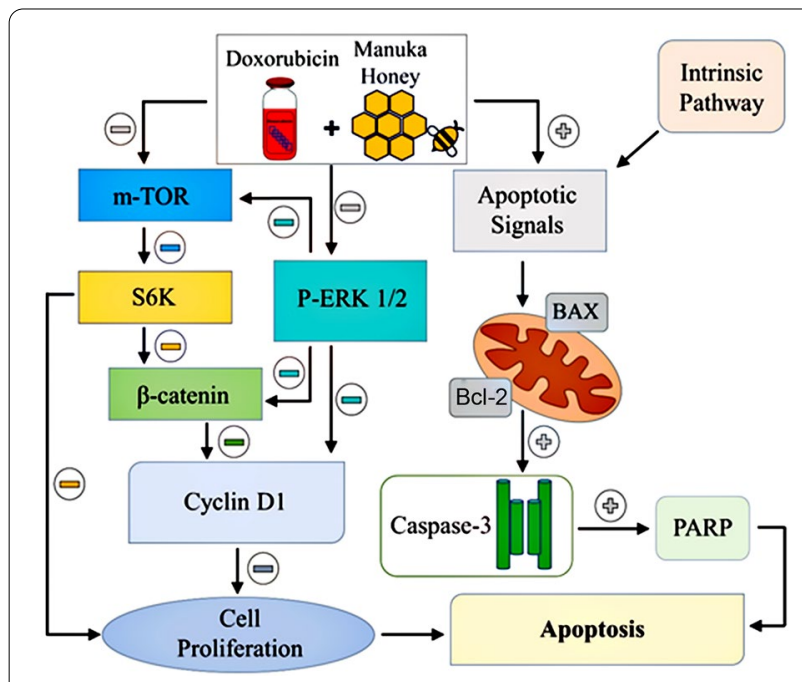

Fig. 6 Proposed schematic overview of apoptosis induced by $\mathrm{MH}$ via modulation of signaling pathways that involved in HCC proliferation and apoptotic markers in human HepG2 cell line

atmospheric humidity (Laminar Air Flow Cabinet "Safety Cabinet" type II \& $\mathrm{CO}_{2}$ Incubator, Shell, USA). Primary human normal neonatal liver cultures (PHNL) were established at Georgetown University, using the conditional reprogramming $(\mathrm{CR})$ of the cell method as previously described [80]. All collected tissue samples and the research protocols were performed in accordance with the Institutional Review Board and approved by the ethical committee of GU Hospital and GU Medical Center, USA (Protocol's No. MOD00001211). Mycoplasma detection assay was performed by Lombardi Tissue Culture \& Bio-banking Shared Resource (TCBSR,) using MycoAlert detection kit (cat \#LT-07118, Lonza Nottingham, LTD). The PHNL-CR cells were carried in culture for over 30 passages. All comparative studies were performed, using the earliest and most comparable passages available.

\section{Drug and compounds}

Manuka honey (MH) (UMF 10+, Ultra-pure honey for a medical grade, Advancis Medical, Nottingham, UK) was diluted to different concentrations (\% w/v) in culture medium for use. All preparations of $\mathrm{MH}$ were freshly prepared on the day of use. Doxorubicin (DOX) was purchased from Sigma Aldrich (St. Louis, MO, USA) and before each experiment, the drug was diluted to the required final concentration in the culture medium.

\section{MTT cell proliferation assay}

HepG2 and Hep3B cells were cultured till mid-log phase in $100 \mu \mathrm{L}$ of medium and seeded in a 96-well plate at a density of $1 \times 10^{4}$ cells/well for $24 \mathrm{~h}$ before treatment. The seeding media was then changed to media with different concentrations $(1.25 \%$ to $20 \%$ ) of $\mathrm{MH}$ (untreated cells were used as the negative control) for $48 \mathrm{~h}$. Then $10 \mu \mathrm{L}$ of the $12 \mathrm{mM}$ MTT stock solution (Invitrogen Corporation, CA, USA) was added to each well. After incubation for $4 \mathrm{~h}$ at $37^{\circ} \mathrm{C}, 100 \mu \mathrm{L}$ of the prepared SDS-HCL solution (10 ml of $0.01 \mathrm{M} \mathrm{HCL}$ was added to one tube containing $1 \mathrm{~g}$ SDS mixed gently by sonication) were added to each well and mixed thoroughly, using the pipette. The microplate was incubated at $37{ }^{\circ} \mathrm{C}$ for $18 \mathrm{~h}$ in a $\mathrm{CO}_{2}$ incubator. The absorbance was then measured at $545 \mathrm{~nm}$ using a microplate ELISA reader (Enzyme-linked immunosorbent assay reader, ELISA Unit, Stat Fax 2100, USA) and $\mathrm{IC}_{50}$ was determined. To achieve significant quantitative analysis, experiments were repeated in triplicate in parallel for each concentration and compared to untreated control experiments.

\section{Cell morphology}

Equal numbers of HepG2 cells/well in supplemented DMEM medium were seeded in 12-well culture plates. The cells were treated with $1 / 2 \mathrm{IC}_{50} \mathrm{MH}, 1 \mu \mathrm{M}$ Doxorubicin, as a positive control, or $1 \frac{1}{2} \mathrm{IC}_{50} \mathrm{MH}$ plus $1 \mu \mathrm{M}$ DOX as a combined treatment. The cells were incubated in 5\% $\mathrm{CO}_{2}$ at $37{ }^{\circ} \mathrm{C}$ for $48 \mathrm{~h}$, washed with cold PBS (1X), and fixed with $10 \%$ buffered formalin [81]. Cells were examined by inverted microscopy at $400 \times$ magnification (Inverted Microscope, Optika, Italy). Digital images were acquired with a Kodak microscopic digital camera.

\section{Flow cytometry analysis of apoptosis}

To determine apoptotic cell death, annexin-V-positive cells and the ratio of sub-G1 were analyzed by flow cytometry (BD Sciences, Franklin Lakes, NJ, USA). Annexin-V (AV) assay was performed to quantify early and late apoptosis in HepG2 cells treated with $\mathrm{IC}_{50} \mathrm{MH}$, $1 \mu \mathrm{M}$ DOX, or $1 / 2 \mathrm{IC}_{50} \mathrm{MH}+1 \mu \mathrm{M}$ DOX combined treatment compared to untreated cells. This assay was performed by flow cytometry, utilizing Annexin V-FITC/PI apoptosis detection kit according to the manufacturer's protocol (Becton Dickinson, CA, USA). Briefly, HepG2 cells were seeded at a density of $2 \times 10^{5}$ in a 6 -well plate, treated with $\mathrm{IC}_{50} \mathrm{MH}, 1 \mu \mathrm{M}$ DOX, or $1 / 2 \mathrm{IC}_{50} \mathrm{MH}+1 \mu \mathrm{M}$ DOX combined treatment and incubated for $48 \mathrm{~h}$. Cells were collected and stained with AV-fluorescein isothiocyanate (FITC) and Propidium iodide (PI), and quadrant statistics were used to identify early and late apoptotic cells. To measure the sub-G1 DNA population and apoptotic cell death of Hep3B cells, cells were stained by PI solution and FITC annexin- $\mathrm{V}$, respectively, and analyzed with the flow cytometer. 


\section{Caspase- 3 activity}

The caspase 3 colorimetric assay is based on the hydrolysis of the peptide substrate acetyl-Asp-Glu-ValAsp p-nitroanilide (Ac-DEVD-pNA) by caspase 3, resulting in the release of the p-nitroaniline (pNA) moiety. $\mathrm{p}$-Nitroaniline has a high absorbance at $405 \mathrm{~nm}$. The concentration of the pNA released from the substrate is calculated from the absorbance values at $405 \mathrm{~nm}$ or from a calibration curve prepared with defined pNA solutions. Caspase- 3 activity was assayed, according to the manufacturer's protocol of colorimetric assay kit (Bio Vision, Inc., CA, USA) that provides quick and efficient detection of caspase- 3 activity in cell lysates and purified preparations of caspase-3. $5 \times 10^{6}$ cells were treated with $\mathrm{MH}$, DOX or ( $1 / 2 \mathrm{IC} 50 \mathrm{MH}+1 \mu \mathrm{M}$ DOX) combined treatment and lysed in $100 \mu \mathrm{L}$ lysis buffer containing $10 \mathrm{mM}$ HEPES (4-(2-hydroxyethyl)-1-piperazine ethane sulfonic acid), pH 7.4, 2 mM EDTA, 0.1\% CHAPS (3-[(3-cholamidoprpyl) dimethyl ammonio]-1-prpropane sulfsulfonic acidacid $0 \mu \mathrm{g} / \mathrm{mL}$ PMSF (phenyl methane sulfonyl fluoride or phenylmethylsulfonylfluoride), and $5 \mathrm{mM}$ DTT (Dithiothreitol). Cells were homogenized by three cycles of freezing and thawing and then centrifuged to remove the cellular debris. Each sample was then incubated in buffer containing $10 \mathrm{mM}$ HEPES, pH 7.4, 2 mM EDTA, $0.1 \%$ CHAPS, and $5 \mathrm{mM}$ EDTA supplemented with its substrate (AcAsp-Glu-Val-Asp-AFC) Ac-DEVD-AFC for $1 \mathrm{~h}$ at room temperature and the reaction was stopped with $1 \mathrm{~N} \mathrm{HCl}$. Optical density was measured using a spectrophotometer at $405 \mathrm{~nm}$ (Jenway Spectrophotometer, UK). The data are expressed as relative fold increase compared to control (non-treated cells). Each assay was done in triplicate and the standard error of the mean was determined.

\section{Apoptosis induction assay (ELISA)}

An ELISA assay was performed, using Cell Death Detection ELISA PLUS Kit (Roche-Applied Science, Indianapolis, USA) that measures histone release from fragmented DNA in apoptotic cells. Firstly, cells were seeded $\left(2 \times 10^{4}\right)$ in a 96-well plate for $24 \mathrm{~h}$, then incubated for $48 \mathrm{~h}$ in media contain $\mathrm{MH}$, DOX, or combined treatment. Cells were lysed with $200 \mu \mathrm{L}$ lysis buffer for $30 \mathrm{~min}$ at $4{ }^{\circ} \mathrm{C}$, the lysates were subjected to centrifugation for $10 \mathrm{~min}$ then, and $20 \mu \mathrm{l}$ of the collected supernatant was incubated with anti-histone biotin and anti-DNA peroxidase for $2 \mathrm{~h}$ at room temperature. After three washes with the incubation buffer, $100 \mu \mathrm{l}$ of substrate solution $\left(2,2^{\prime}\right.$-azinodi (3-ethylbenzthiazoline-sulphuric acid)) was added to each well and incubated for $15 \mathrm{~min}$ at room temperature followed by the addition of $100 \mu \mathrm{l}$ ABTS stop solution. Finally, the absorbance was measured using an ELISA reader (Jenway Spectrophotometer, UK) at $405 \mathrm{~nm}$. Each assay was performed in triplicate and the standard error of the mean was determined.

\section{Western blot analysis}

HepG2 cells were plated in $25 \mathrm{~cm}^{2}$ flask and incubated under cell culture conditions. $\left(37^{\circ} \mathrm{C}, 5 \% \mathrm{CO}_{2}\right)$. On the following day, cells were treated with fresh medium containing $\mathrm{MH}$, DOX, or $(1 / 10 \mathrm{IC} 50 \mathrm{MH}+1 \mu \mathrm{M}$ DOX and $1 / 2$ $\mathrm{IC}_{50} \mathrm{MH}+1 \mu \mathrm{M}$ DOX) combined treatment. After $48 \mathrm{~h}$, cells were harvested, washed in phosphate-buffered saline (PBS), and lysed in lysis buffer [250 $\mathrm{mM} \mathrm{NaCl}$, $25 \mathrm{mM}$ Tris-Cl (pH 7.5), 5 mM EDTA (pH 8.0), 1\% NP-40, $1 \mathrm{mM}$ 4-(2-aminoethyl) benzenesulfonyl fluoride hydrochloride, $5 \mathrm{mM}$ dithiothreitol, and protease inhibitor cocktail] followed by centrifugation at 15,000 r.p.m for $30 \mathrm{~min}$ at $4{ }^{\circ} \mathrm{C}$. The supernatants were collected, and the protein concentrations of the collected lysates were determined, using the BCA protein assay kit (Thermo Fisher Scientific Inc., Rockford, IL, USA). Samples were prepared to be loaded on the gel by adding 2-mercaptoethanol (Fluka Sigma-Aldrich, St. Louis, Missouri, USA), distilled water, and 4X Laemmli buffer as a loading buffer then denatured by boiling at $98{ }^{\circ} \mathrm{C}$ for $5 \mathrm{~min} .20 \mu \mathrm{g} / \mu \mathrm{L}$ of total protein were loaded per mini-gel well and separated on 10\% Tris-SDS-PAGE gels (Sodium Dodecyl Sulphate Polyacrylamide Gel Electrophoresis) (Vertical Electrophoresis Unit, Bio-Rad, Laboratories, USA) at $90-120 \mathrm{~V}$ at $2 \mathrm{~h}$. The separated proteins were transferred to UltraCruz ${ }^{\mathrm{TM}}$ nitrocellulose pure transfer membrane (Santa Cruz Biotechnology, CA, USA), using the protein blotting device (Bio-Rad, Laboratories, USA) containing transfer buffer. The membrane was blocked with $3 \%$ BSA solution in TBST buffer (TBS $1 \mathrm{X}$ (10 mM Tris $\mathrm{HCl}$, $\mathrm{pH} 7.4,150 \mathrm{mM} \mathrm{NaCl}$ ) and $0.1 \%$ Tween 20) for $1 \mathrm{~h}$ under agitation. After blocking, the membrane was incubated overnight with the primary antibody at $4{ }^{\circ} \mathrm{C}$ as the following: anti- $\beta$-catenin, anti-cyclin D1, anti-total ERK1/2, anti-pERK1/2, anti-mTOR, anti-S6K, anti-PARP, antiBcl-2, and anti-Bax, (1:1000; Santa Cruz Biotechnology, CA, USA). The expression of the $\beta$-actin protein (SigmaAldrich, St. Louis, Missouri, USA) was used as a loading control for protein normalization. Following incubation with the primary antibodies, the membrane was washed three times in TBST with agitation. The membrane was subsequently probed with the appropriate horseradish peroxidase (HRP-) conjugated secondary antibody (antimouse or antirabbit) (1:5000; Santa Cruz Biotechnology, CA, USA) for $1 \mathrm{~h}$ at room temperature with agitation followed by three washes with TBST buffer, and finally, the membranes were developed by an enhanced chemiluminescent reagent (Amersham Biosciences, Westborough, MA, USA), and then photographed. Densitometry of the developed bands was performed, using Quantity One 
Analysis Software (Bio-Rad Laboratories, USA). Membranes were stripped using blot stripping buffer (Thermo Scientific, IL, USA) and re-probed with anti- $\beta$-actin as a control for equal loading.

\section{Statistical analysis}

The results were presented as the mean $\pm S D M$ of at least three independent experiments. A one-way analysis of variance (ANOVA) was performed using SPSS-IBM software, version 20 (SPSS Inc., Chicago, IL, USA) followed by Tukey's honestly significant difference (HSD) post hoc test $(\mathrm{P}<0.05)$. $P$ vaP-value calculated versus control cells: ${ }^{*} \mathrm{P}$-value $<0.05$; ${ }^{* *} \mathrm{P}<0.01$ and $* *: \mathrm{P}<0.001$ were considered statistically significant.

\begin{abstract}
Abbreviations
Akt: Protein kinase B; AV: Annexin-V; Bcl-2: B-cell lymphoma-2; Bax: Bcl-2 associated $X$ protein; cyclin D1: Cyclin-dependent protein kinase activity in G1 of the cell cycle; DOX: Doxorubicin; DMEM: Dulbecco's modified Eagle's medium; Erk1/2: Extracellular signal-regulated kinase 1/2; FBS: Fetal bovine serum; FITC: Fluorescein isothiocyanate; HCC: Hepatocellular carcinoma; HPLC: High-performance liquid chromatography; HEPES: 4-(2-Hydroxyethyl)-1-piperazine ethane sulfonic acid; h: Hour; IC50: The half maximal inhibitory concentration; $\mathrm{MH}$ : Manuka honey; mTOR: Mammalian target of rapamycin; PARP: Poly (ADP-ribose) polymerase; PBS: Phosphatebuffered saline; PI: Propidium iodide; ROS: Reactive oxygen species; S6K: Ribosomal protein S6 kinase; SDS-PAGE: Sodium Dodecyl Sulphate Polyacrylamide Gel Electrophoresis; TOP2B: Topoisomerase 2b; TBST: Tris-buffered saline containing Tween-20; r.p.m: Round per minute; UMF: Unique manuka factor.
\end{abstract}

\section{Acknowledgements}

The authors wish to express appreciation to Dr. Mahmoud Ibrahim for his valuable comments. We apologize to those authors whose original works were not cited due to space limitations.

\section{Authors' contributions}

$\mathrm{HA}, \mathrm{AN}, \mathrm{MW}, \mathrm{ME}$, and AS designed the study. HA and AS performed the experiments, analysed/interpreted data, statistical analysis, and wrote the manuscript. ME checked English and drafted the manuscript. CA, MUC, and AS isolated, cultured, characterized, and prepared the data of primary human neonatal liver cells. All authors read and approved the final manuscript.

\section{Funding}

Not applicable.

\section{Availability of data and materials}

The datasets used and/or analyzed during the current study are available from the corresponding author on reasonable request.

\section{Declarations}

Ethics approval and consent to participate

Primary human normal neonatal liver cultures (PHNL) were established at Georgetown University, using the conditional reprogramming (CR). All collected tissue samples and the research protocols were performed in accordance with the Institutional Review Board and approved by the ethical committee of GU Hospital and GU Medical Center, USA (Protocol's No. MOD00001211)

\section{Consent for publication}

Not applicable.

\section{Competing interests}

The authors declare that they have no competing interests, financial or otherwise.

\section{Author details}

${ }^{1}$ Biochemistry Department, Faculty of Science, Alexandria University, Alexandria, Egypt. ${ }^{2}$ Oncology and Radiology Departments, Lombardi Comprehensive Cancer Center, Georgetown University Medical Center, Washington, DC, USA. ${ }^{3}$ Department of Medical Laboratory Technology, Faculty of Applied Health Sciences Technology, Pharos University, Alexandria, Egypt. ${ }^{4}$ Oncology Department, Lombardi Comprehensive Cancer Center, Georgetown University Medical Center, Washington, DC, USA.

Received: 27 September 2020 Accepted: 3 May 2021

Published online: 28 May 2021

\section{References}

1. Ferlay J, Soerjomataram I, Dikshit R, Eser S, Mathers C, Rebelo M, et al. Cancer incidence and mortality worldwide: sources, methods and major patterns in GLOBOCAN 2012. Int J Cancer. 2015;136(5):E359-86. https:// doi.org/10.1002/ijc.29210.

2. Lozano R, Naghavi M, Foreman K, Lim S, Shibuya K, Aboyans V, et al. Global and regional mortality from 235 causes of death for 20 age groups in 1990 and 2010: a systematic analysis for the Global Burden of Disease Study 2010. Lancet. 2013;380(9859):2095-128. https://doi.org/10.1016/ S0140-6736(12)61728-0.

3. Shaker MK, Abdella HM, Khalifa MO, Dorry AKE. Epidemiological characteristics of hepatocellular carcinoma in Egypt: a retrospective analysis of 1313 cases. Liver Int. 2013;33(10):1601-6. https://doi.org/10.1111/liv. 12209.

4. Omar A, Abou-Alfa GK, Khairy A, Omar H. Risk factors for developing hepatocellular carcinoma in Egypt. Chin Clin Oncol. 2013;2(4):43-51. https://doi.org/10.3978/j.issn.2304-3865.2013.11.07.

5. Zekri A, Youssef A, Bakr YM, Gabr RM, El-Rouby M, Hammad I, et al. Serum biomarkers for early detection of hepatocellular carcinoma associated with HCV infection in Egyptian patients. Asian Pac J Cancer Prev. 2015;16(3):1281-7. https://doi.org/10.7314/apjcp.2015.16.3.1281.

6. Jemal A, Bray F, Center MM, Ferlay J, Ward E, Forman D. Global cancer statistics. CA Cancer J Clin. 2011;61(2):69-90. https://doi.org/10.3322/ caac. 20107.

7. Sultan AS, Sel G, Hessien M, el Mahmoud S, Ibrahim AS, Sherif ZA. Molecular markers of hepatitis C virus-related hepatocellular carcinoma. Cancer Biol Ther. 2006;5(6):623-9. https://doi.org/10.4161/cbt.5.6.2674.

8. Au JS, Frenette CT. Management of hepatocellular carcinoma: current status and future directions. Gut Liver. 2015;9(4):437-48. https://doi.org/ 10.5009/gnl15022.

9. Sun J, Liu RH. Cranberry phytochemical extracts induce cell cycle arrest and apoptosis in human MCF-7 breast cancer cells. Cancer Lett. 2006;241(1):124-34. https://doi.org/10.1016/j.canlet.2005.10.027.

10. Morgan DO. Cyclin-dependent kinases: engines, clocks, and microprocessors. Annu Rev Cell Dev Biol. 1997;13(1):261-91. https://doi.org/10.1146/ annurev.cellbio.13.1.261.

11. Abdelmonsif DA, Sultan AS, El-Hadidy WF, Abdallah DM. Targeting AMPK, $\mathrm{mTOR}$, and $\beta$-Catenin by combined metformin and aspirin therapy in hcc: an appraisal in Egyptian HCC patients. Mol Diagn Ther. 2018;22(1):115-27. https://doi.org/10.1007/s40291-017-0307-7.

12. Perez-Camino M, Cert A. Quantitative determination of hydroxy pentacyclic triterpene acids in vegetable oils. J Agric Food Chem. 1999:47(4):1558-62. https://doi.org/10.1021/jf980881h.

13. Othman NH. Honey and cancer: sustainable inverse relationship particularly for developing nations - a review. Evid-Based Compl Alt Med. 2012;2012:410406-15. https://doi.org/10.1155/2012/410406.

14. Gupta SS, Singh O, Bhagel PS, Moses S, Shukla S, Mathur RK. Honey dressing versus silver sulfadiazene dressing for wound healing in burn patients: a retrospective study. J Cutan Aesthet Surg. 2011;4(3):183-7. https://doi.org/10.4103/0974-2077.91249.

15. Erejuwa OO, Sulaiman SA, Ab Wahab MS. Honey: a novel antioxidant. Molecules. 2012;17(4):4400-23. https://doi.org/10.3390/molecules170444 00. 
16. Erejuwa OO, Sulaiman SA, Wahab MSA, Sirajudeen KNS, Salleh MSM, Gurtu S. Antioxidant protective effect of glibenclamide and metformin in combination with honey in pancreas of streptozotocin-induced diabetic rats. Int J Mol Sci. 2010;11(5):2056-66. https://doi.org/10.3390/ijms110520 56.

17. Erejuwa OO, Gurtu S, Sulaiman SA, Wahab MSA, Sirajudeen K, Salleh MSM. Hypoglycemic and antioxidant effects of honey supplementation in streptozotocin-induced diabetic rats. Int J Vitam Nutr Res. 2010;80(1):7482. https://doi.org/10.1024/0300-9831/a000008.

18. Sherlock O, Dolan A, Athman R, Power A, Gethin G, Cowman S, et al. Comparison of the antimicrobial activity of Ulmo honey from Chile and Manuka honey against methicillin-resistant Staphylococcus aureus, Escherichia coli, and Pseudomonas aeruginosa. BMC Complement Altern Med. 2010;10(1):47-51. https://doi.org/10.1186/1472-6882-10-47.

19. Mandal MD, Mandal S. Honey: its medicinal property and antibacterial activity. Asian Pac J Trop Biomed. 2011;1 (2):154-60. https://doi.org/10. 1016/S2221-1691(11)60016-6.

20. Ng WJ, Ken KW, Kumar RV, Gunasagaran H, Chandramogan V, Lee YY. In-vitro screening of Malaysian honey from different floral sources for antibacterial activity on human pathogenic bacteria. Afr J Tradit Complement Altern Med. 2014;11(2):315-8. https://doi.org/10.4314/ajtcam.v1 1i2. 14

21. Al-Waili NS. Natural honey lowers plasma glucose, C-reactive protein, homocysteine, and blood lipids in healthy, diabetic, and hyperlipidemic subjects: comparison with dextrose and sucrose. J Med Food. 2004;7(1):100-7. https://doi.org/10.1089/109662004322984789.

22. Swellam T, Miyanaga N, Onozawa M, Hattori K, Kawai K, Shimazui T, et al. Antineoplastic activity of honey in an experimental bladder cancer implantation model: in vivo and in vitro studies. Int J Urol. 2003;10(4):213-9. https://doi.org/10.1046/j.0919-8172.2003.00602.x.

23. Sergiel I, Pohl P, Biesaga M. Characterisation of honeys according to their content of phenolic compounds using high-performance liquid chromatography/tandem mass spectrometry. Food Chem. 2014;145:404-8. https://doi.org/10.1016/j.foodchem.2013.08.068.

24. Chan CW, Deadman BJ, Manley-Harris M, Wilkins AL, Alber DG, Harry E. Analysis of the flavonoid component of bioactive New Zealand mānuka (Leptospermum scoparium) honey and the isolation, characterization, and synthesis of an unusual pyrrole. Food Chem. 2013;141(3):1772-81. https://doi.org/10.1016/j.foodchem.2013.04.092.

25. Yao L, Datta N, Tomás-Barberán FA, Ferreres F, Martos I, Singanusong R. Flavonoids, phenolic acids and abscisic acid in Australian and New Zealand Leptospermum honeys. Food Chem. 2003;81(2):159-68. https:// doi.org/10.1016/S0308-8146(02)00388-6.

26. Fernandez-Cabezudo MJ, El-Kharrag R, Torab F, Bashir G, George JA, El-Taji $\mathrm{H}$, et al. Intravenous administration of manuka honey inhibits tumor growth and improves host survival when used in combination with chemotherapy in a melanoma mouse model. PLoS ONE. 2013;8(2):e55993-6104. https://doi.org/10.1371/journal.pone.0055993.

27. Alvarez-Suarez JM, Gasparrini M, Forbes-Hernández TY, Mazzoni L, Giampieri F. The composition and biological activity of honey: a focus on Manuka honey. Foods. 2014;3(3):420-32. https://doi.org/10.3390/foods 3030420.

28. Adams CJ, Boult CH, Deadman BJ, Farr JM, Grainger MN, Manley-Harris M, et al. Isolation by HPLC and characterization of the bioactive fraction of New Zealand manuka (Leptospermum scoparium) honey. Carbohydr Res. 2008;343(4):651-9. https://doi.org/10.1016/j.carres.2007.12.011.

29. Karasawa K, Haraya S, Okubo S, Arakawa H. Novel assay of antibacterial components in manuka honey using lucigenin-chemiluminescenceHPLC. Anal Chim Acta. 2017;954:151-8. https://doi.org/10.1016/j.aca. 2016.12.004.

30. Alvarez-Suarez JM, Giampieri F, Cordero M, Gasparrini M, Forbes-Hernández TY, Mazzoni L, et al. Activation of AMPK/Nrf2 signaling by Manuka honey protects human dermal fibroblasts against oxidative damage by improving antioxidant response and mitochondrial function promoting wound healing. J Funct Foods. 2016;25:38-49. https://doi.org/10.1016/j. jff.2016.05.008.

31. Afrin S, Giampieri F, Gasparrini M, Forbes-Hernández TY, Cianciosi D, Reboredo-Rodriguez $\mathrm{P}$, et al. The inhibitory effect of Manuka honey on human colon cancer HCT-116 and LoVo cell growth. Part 1: the suppression of cell proliferation, promotion of apoptosis and arrest of the cell cycle. Food Funct. 2018;9(4):2145-57. https://doi.org/10.1039/c8fo0 $0164 b$

32. Frydman GH, Olaleye D, Annamalai D, Layne K, Yang I, Kaafarani HM, et al. Manuka honey microneedles for enhanced wound healing and the prevention and/or treatment of Methicillin-resistant Staphylococcus aureus (MRSA) surgical site infection. Sci Rep. 2020;10(1):1-11. https://doi.org/10. 1038/s41598-020-70186-9.

33. Chatterjee K, Zhang J, Honbo N, Karliner JS. Doxorubicin cardiomyopathy. Cardiology. 2010;115(2):155-62. https://doi.org/10.1159/000265166.

34. Mobaraki M, Faraji A, Zare M, Dolati P, Ataei M, Manshadi HD. Molecular mechanisms of cardiotoxicity: a review on major side-effect of Doxorubicin. Indian J Pharm Sci. 2017;79:335-44. https://doi.org/10.4172/pharm aceutical-sciences. 1000235.

35. Takemura G, Fujiwara H. Doxorubicin-induced cardiomyopathy from the cardiotoxic mechanisms to management. Prog Cardiovasc Dis. 2007;49(5):330-52. https://doi.org/10.1016/j.pcad.2006.10.002.

36. Lee JS, Hong EK. Agaricus blazei Murill enhances doxorubicin-induced apoptosis in human hepatocellular carcinoma cells by NFkB-mediated increase of intracellular doxorubicin accumulation. Int $\mathrm{J}$ Oncol. 2011;38(2):401-8. https://doi.org/10.3892/ijo.2010.852.

37. Cervello M, McCubrey JA, Cusimano A, Lampiasi N, Azzolina A, Montalto G. Targeted therapy for hepatocellular carcinoma: novel agents on the horizon. Oncotarget. 2012;3(3):236-60. https://doi.org/10.18632/oncot arget.466.

38. Ozben T. Oxidative stress and apoptosis: impact on cancer therapy. J Pharm Sci. 2007;96(9):2181-96. https://doi.org/10.1002/jps.20874.

39. Huynh H, Nguyen TT, Chow KK, Tan PH, Soo KC, Tran E. Over-expression of the mitogen-activated protein kinase (MAPK) kinase (MEK)-MAPK in hepatocellular carcinoma: its role in tumor progression and apoptosis. BMC Gastroenterol. 2003;3(1):19-39. https://doi.org/10.1186/ 1471-230X-3-19.

40. Ghashm AA, Othman NH, Khattak MN, Ismail NM, Saini R. Antiproliferative effect of Tualang honey on oral squamous cell carcinoma and osteosarcoma cell lines. BMC Complement Altern Med. 2010;10(1):49-61. https:// doi.org/10.1186/1472-6882-10-49.

41. Chen H, Liu RH. Potential mechanisms of action of dietary phytochemicals for cancer prevention by targeting cellular signaling transduction pathways. J Agric Food Chem. 2018;66(13):3260-76. https://doi.org/10. 1021/acs.jafc.7b04975.

42. Liu RH. Potential synergy of phytochemicals in cancer prevention: mechanism of action. J Nutr. 2004;134(12):3479S-S3485. https://doi.org/ 10.1093/jn/134.12.3479S.

43. Marshall SM, Schneider KR, Cisneros KV, Gu L. Determination of antioxidant capacities, a-dicarbonyls, and phenolic phytochemicals in Florida varietal honeys using HPLC-DAD-ESI-MS n. J Agric Food Chem. 2014;62(34):8623-31. https://doi.org/10.1021/jf501329y.

44. Portokalakis I, Yus of H, Ghanotakis D, Nigam PS, Owusu-Apenten R. Manuka Honey-induced cytotoxicity against MCF7 breast cancer cells is correlated to total phenol content and antioxidant power. J Adv Biol Biotech. 2016;8(2):1-10. https://doi.org/10.9734/JABB/2016/27899.

45. Badolato M, Carullo G, Cione E, Aiello F, Caroleo MC. From the hive: Honey, a novel weapon against cancer. Eur J Med Chem. 2017;142:290-9. https://doi.org/10.1016/j.ejmech.2017.07.064.

46. Lee KW, Bode AM, Dong Z. Molecular targets of phytochemicals for cancer prevention. Nat Rev Cancer. 2011;11(3):211-8. https://doi.org/10. 1038/nrc3017.

47. Fan Y, Liu J, Liu D, Zhou Z, Bao Y, Wang J, et al. NSCA-1 — a novel $\mathrm{N}$-substituted coumalamide derivative-increases Adriamycin sensitivity in HepG2/adriamycin cells through modulating Akt/GSK-3 3 signaling and p53-dependant apoptotic pathway. Environ Toxicol Pharmacol. 2017:49:1-7. https://doi.org/10.1016/j.etap.2016.09.012.

48. Gao A, Zhang X, Ke Z. Apigenin sensitizes BEL-7402/ADM cells to doxorubicin through inhibiting miR-101/Nrf2 pathway. Oncotarget. 2017:8(47):82085-91. https://doi.org/10.18632/ontarget.18294.

49. Jänicke RU, Sprengart ML, Wati MR, Porter AG. Caspase-3 is required for DNA fragmentation and morphological changes associated with apoptosis. J Biol Chem. 1998;273(16):9357-60. https://doi.org/10.1074/jbc.273. 16.9357.

50. Lakhani SA, Masud A, Kuida K, Porter GA, Booth CJ, Mehal WZ, et al. Caspases 3 and 7: key mediators of mitochondrial events of apoptosis. 
Science. 2006;311(5762):847-51. https://doi.org/10.1126/science.11150 35.

51. Liu X, Zou H, Slaughter C, Wang X. DFF, a heterodimeric protein that functions downstream of caspase-3 to trigger DNA fragmentation during apoptosis. Cell. 1997;89(2):175-84. https://doi.org/10.1016/s00928674(00)80197-X.

52. Corbiere C, Liagre B, Terro F, Beneytout J. Induction of antiproliferative effect by diosgenin through activation of $\mathrm{p} 53$, release of apoptosisinducing factor (AIF), and modulation of caspase-3 activity in different human cancer cells. Cell Res. 2004;14(3):188-96. https://doi.org/10.1038/ sj.cr.7290219.

53. Zhang Q, Ma S, Liu B, Liu J, Zhu R, Li M. Chrysin induces cell apoptosis via activation of the $\mathrm{p} 53 / \mathrm{BCl}-2 /$ caspase-9 pathway in hepatocellular carcinoma cells. Exp Ther Med. 2016;12(1):469-74. https://doi.org/10.3892/ etm.2016.3282.

54. Im E, Yeo C, Lee E. Luteolin induces caspase-dependent apoptosis via inhibiting the AKT/osteopontin pathway in human hepatocellular carcinoma SK-Hep-1 cells. Life Sci. 2018;209:259-66. https://doi.org/10.1016/j. Ifs.2018.08.025.

55. Dai W, Gao Q, Qiu J, Yuan J, Wu G, Shen G. Quercetin induces apoptosis and enhances 5-FU therapeutic efficacy in hepatocellular carcinoma. Tumour Biol. 2016;37(5):6307-13. https://doi.org/10.1007/ s13277-015-4501-0.

56. Tahir AA, Sani NFA, Murad NA, Makpol S, Ngah WZW, Yusof YAM. Combined ginger extract \& Gelam honey modulate Ras/ERK and PI3K AKT pathway genes in colon cancer HT29 cells. Nutr J. 2015;14(1):31-47. https://doi.org/10.1186/s12937-015-0015-2.

57. Ding Y, Chen X, Wang B, Yu B, Ge J, Shi X. Quercetin suppresses the chymotrypsin-like activity of proteasome via inhibition of MEK1/ERK1/2 signaling pathway in hepatocellular carcinoma HepG2 cells. Can J Physiol Pharmacol. 2018:96(5):521-6. https://doi.org/10.1139/cjpp-2017-0655.

58. Shao H, Jing K, Mahmoud E, Fang X, Yu C. Modulation of AKT, ERK, and Mcl-1 by apigenin sensitizes colon cancer cells to anti-tumor activities of ABT263. Mol Cancer Ther. 2013;12(12):10-22. https://doi.org/10.1158/ 1535-7163.MCT-13-0066.

59. Jin C, Samuelson L, Cui C-B, Sun Y, Gerber DA. MAPK/ERK and Wnt/Bcatenin pathways are synergistically involved in proliferation of Sca-1 positive hepatic progenitor cells. Biochem Biophys Res Commun. 2011;409(4):803-7. https://doi.org/10.1016/j.bbrc.2011.05.094.

60. Sahin F, Kannangai R, Adegbola O, Wang J, Su G, Torbenson M. mTOR and P70 S6 kinase expression in primary liver neoplasms. Clin Cancer Res. 2004;10(24):8421-5. https://doi.org/10.1158/1078-0432.CCR-04-0941.

61. Morris SL, Huang S. Crosstalk of the Wnt/B-catenin pathway with other pathways in cancer cells. Genes Dis. 2016;3(1):41-7. https://doi.org/10. 1016/j.gendis.2015.12.003.

62. Mendoza MC, Er EE, Blenis J. The Ras-ERK and PI3K-mTOR pathways: crosstalk and compensation. Trends Biochem Sci. 2011;36(6):320-8. https://doi. org/10.1016/j.tibs.2011.03.006.

63. Shan BE, Wang M, Li R. Quercetin inhibits human SW480 colon cancer growth in association with inhibition of cyclin D1 and survivin expression through Wnt/B-catenin signaling pathway. Cancer Invest. 2009;27(6):60412. https://doi.org/10.1080/07357900802337191.

64. Ji Y, Li L, Ma Y, Li W, Li L, Zhu H, et al. Quercetin inhibits growth of hepatocellular carcinoma by apoptosis induction in part via autophagy stimulation in mice. J Nutr Biochem. 2019;69:108-19. https://doi.org/10.1016/j. jnutbio.2019.03.018.

65. Pratheeshkumar P, Son Y, Budhraja A, Wang X, Ding S, Wang L, et al, Luteolin inhibits human prostate tumor growth by suppressing vascular endothelial growth factor receptor 2-mediated angiogenesis. PLoS ONE. 2012;7(12):e52279. https://doi.org/10.1371/journal.pone.0052279.

66. Anson DM, Wilcox RM, Huseman ED, Stump TA, Paris RL, Darkwah BO, et al. Luteolin decreases epidermal growth factor receptor-mediated cell proliferation and induces apoptosis in glioblastoma cell lines. Basic Clin Pharmacol. 2018;123(6):678-86. https://doi.org/10.1111/bcpt.13077.

67. Sadot $E$, Geiger B, Oren M, Ben-Ze'ev A. Down-regulation of $\beta$-catenin by activated p53. Mol Cell Biol. 2001;21(20):6768-81. https://doi.org/10. 1128/MCB.21.20.6768-6781.2001.

68. Provost E, Rimm DL. Controversies at the cytoplasmic face of the cadherin-based adhesion complex. Curr Opin Cell Biol. 1999;1 1(5):567-72. https://doi.org/10.1016/s0955-0674(99)00015-0.

69. Liu J, Stevens J, Rote CA, Yost HJ, Hu Y, Neufeld KL, et al. Siah-1 mediates a novel $\beta$-catenin degradation pathway linking p53 to the adenomatous polyposis coli protein. Mol Cell. 2001;7(5):927-36. https://doi.org/10. 1016/s1097-2765(01)00241-6.

70. Pez F, Lopez A, Kim M, Wands JR, de Fromentel CC, Merle P. Wnt signaling and hepatocarcinogenesis: molecular targets for the development of innovative anticancer drugs. J Hepatol. 2013;59(5):1107-17. https://doi. org/10.1016/j.jhep.2013.07.001.

71. Benn J, Schneider RJ. Hepatitis B virus HBx protein activates Ras-GTP complex formation and establishes a Ras, Raf, MAP kinase signaling cascade. Proc Natl Acad Sci USA. 1994;91 (22):10350-4. https://doi.org/10.1073/ pnas.91.22.10350.

72. Gwak J, Oh J, Cho M, Bae SK, Song I, Liu K, et al. Galangin suppresses the proliferation of $\beta$-catenin response transcription-positive cancer cells by promoting adenomatous polyposis coli/Axin/glycogen synthase kinase-3 $\beta$-independent $\beta$-catenin degradation. Mol Pharmacol. 2011;79(6):1014-22. https://doi.org/10.1124/mol.110.069591.

73. Wang D, Xiang D, He Y, Li Z, Wu X, Mou J, et al. Effect of caffeic acid phenethyl ester on proliferation and apoptosis of colorectal cancer cells in vitro. World J Gastroenterol. 2005;11 (26):4008-12. https://doi.org/10. 3748/wjg.v11.i26.4008.

74. Solit DB, Garraway LA, Pratilas CA, Sawai A, Getz G, Basso A, et al. BRAF mutation predicts sensitivity to MEK inhibition. Nature. 2006;439(7074):358-62. https://doi.org/10.1038/nature04304.

75. Lavoie JN, L'Allemain G, Brunet A, Müller R, Pouysségur J. Cyclin D1 expression is regulated positively by the p42/p44MAPK and negatively by the p38/HOGMAPK pathway. J Biol Chem. 1996;271(34):20608-16. https://doi.org/10.1074/jbc.271.34.20608.

76. Klein EA, Assoian RK. Transcriptional regulation of the cyclin D1 gene at a glance. J Cell Sci. 2008;121(23):3853-7. https://doi.org/10.1242/jcs. 039131.

77. Parekh P, Rao K. Overexpression of cyclin D1 is associated with elevated levels of MAP kinases, Akt and Pak1 during diethylnitrosamine-induced progressive liver carcinogenesis. Cell Biol Int. 2007;31 (1):35-43. https:// doi.org/10.1016/j.cellbi.2006.09.005.

78. Joo M, Kang YK, Kim MR, Lee HK, Jang JJ. Cyclin D1 overexpression in hepatocellular carcinoma. Liver. 2001;21(2):89-95. https://doi.org/10. 1034/j.1600-0676.2001.021002089.x.

79. Zhou J, Fang L, Liao J, Li L, Yao W, Xiong Z, et al. Investigation of the anti-cancer effect of quercetin on HepG2 cells in vivo. PLoS ONE. 2017;12(3):e0172838. https://doi.org/10.1371/journal.pone.0172838.

80. Liu X, Ory V, Chapman S, Yuan H, Albanese C, Kallakury B, Timofeeva OA, Nealon C, Dakic A, Simic V, Haddad BR. ROCK inhibitor and feeder cells induce the conditional reprogramming of epithelial cells. Am J Pathol. 2012;180(2):599-607. https://doi.org/10.1016/j.ajpath.2011.10.036.

81. Behari J, Zeng G, Otruba W, Thompson MD, Muller P, Micsenyi A, et al. R-Etodolac decreases $\beta$-catenin levels along with survival and proliferation of hepatoma cells. J Hepatol. 2007;46(5):849-57. https://doi.org/10. 1016/j.jhep.2006.11.017.

\section{Publisher's Note}

Springer Nature remains neutral with regard to jurisdictional claims in published maps and institutional affiliations. 